\title{
Profissional da informação: um conceito em construção ${ }^{1}$
}

\author{
The information professional: a concept under construction
}

Mônica de Fátima LOUREIRO²

Paulo de Martino JANNUZZI

\section{R E S U M O}

Para discutir o conceito de Profissional da Informação estudou-se o histórico das profissões ligadas ao tratamento da informação, com ênfase dada ao bibliotecário. Abordou-se ainda a relação entre as áreas da Arquivologia, Biblioteconomia, Ciência da Informação, Documentação e Museologia. Finalmente, compilaram-se alguns trabalhos cujo tema e objeto de estudo era o profissional da informação, visando verificar se há consenso quanto ao conceito de Profissional da Informação, na literatura de Ciência da Informação. Concluiu-se não existir consenso em relação a um conceito que defina quem é o Profissional da Informação. Evidenciou-se, portanto, que esse tema merece mais estudos, tanto para manter a integridade da categoria profissional, como para assegurar o reconhecimento da sua atuação profissional por parte da sociedade.

Palavras-chave: profissional da informação, bibliotecário, atuação profissional.

\section{A B S T R A C T}

To discuss the concept of "Information Professional", a study was performed, focusing on the history of professions related to the processing of information,

\footnotetext{
1 Artigo elaborado a partir da dissertação de M.F. LOUREIRO, intitulada "O bibliotecário como profissional da informação: análise da inserção no mercado de trabalho brasileiro segundo o Censo Demográfico de 2000". Pontifícia Universidade Católica de Campinas, 2004. 131p.

2 Bibliotecária, Mestre em Ciência da Informação, Pontifícia Universidade Católica de Campinas. Rua Armando Sebastião Bonomi, 295, Barão Geraldo, 13084-170, Campinas, SP, Brasil. Correspondência para/Correspondence to: M.F. LOUREIRO. E-mail: <monicaeros@ig.com>.

${ }^{3}$ Doutor em Demografia, Docente, Programa de Pós-Graduação em Ciência da Informação, Pontifícia Universidade Católica de Campinas e da Escola Nacional de Ciências Estatísticas, Instituto Brasileiro de Geografia e Estatística. Rua Gal, Canabarro, 706,2ºndar, Maracanã, 20271-201, Rio de Janeiro, RJ, Brasil. E-mail: <pjannuzzi@mpc.com.br>.

Recebido em 31/1/2005 e aceito para publicação em 18/05/2005.
} 
with emphasis on the librarian functions. The study's approach included an analysis of the relationships among such areas as Archivology, Librarianship, Information Science, Documentation and Museology. Finally, to verify whether the concept of Information Professional had, or not, a consensus in the literature about Information Science, a compilation was made, of selected works whose object of study was the Information Professional. The conclusion was that there is no consensus on such concept, and that this subject deserves more studies, as much to preserve the integrity of the professional category, as to assure the recognition of its function by the society.

Key words: information professional, librarian, professional working field.

\section{N T R O D U Ç Ã O}

Na literatura da Ciência da Informação, é cada vez mais comum o uso de termos como 'profissional' ou 'profissionais da informação', para designar os trabalhadores que têm a informação como seu principal objeto de trabalho (MARCHIORI, 1996; ALMEIDA JR., 2000; GUIMARÃES, 2000; PEREIRA, 2000; PONJUÁN DANTE, 2000; SMIT, 2000; VALENTIM, 2000; DAMASIO, 2001; JANNUZZI; MATTOS, 2001; PEGORARO, 2001; FERREIRA, 2002; NEVES, 2002; RODRIGUES, 2002; TARAPANOFF et al., 2002; CUNHA; CRIVELLARI, 2004; MUELLER, 2004). Em cada estudo, tais termos adquirem contornos específicos, referindo-se tanto à categoria particular de Bibliotecários, como a toda a gama de profissionais de diferentes áreas de formação, tais como Analistas de Sistemas, Administradores de Sistemas, Analistas de Mercado, Consultores Organizacionais, Jornalistas, enfim, profissionais ligados de alguma forma à cadeia de processamento da informação - seja na produção, no tratamento, na análise ou na disseminação.

Se tal elasticidade conceitual proporciona, por um lado, um campo propício de pesquisa na área, por outro, retira-Ihe a especificidade necessária para poder-se enfocar questões importantes acerca da inserção e atividades no mercado de trabalho, dos profissionais egressos de cursos de Biblioteconomia e Ciência da Informação.
Nesse sentido, este trabalho procura contribuir para os estudos na área, ao fazer uma compilação de textos que, além de resgatar o processo histórico de criação e desenvolvimento da ocupação de Bibliotecário, discutem seu papel e os desafios de sua inserção profissional no mundo do trabalho contemporâneo.

\section{O registro da informação como gerador da função de organizador}

O homem, como ser inteligente e social, procurou registrar suas experiências desde os tempos mais remotos. É de conhecimento comum que as primeiras manifestações de inscrição de informações encontram-se em paredes de cavernas, onde os primitivos desenhavam imagens, hoje interpretadas como ligadas às atividades do seu cotidiano, tais como a caça, a pesca e a coleta de alimentos.

Com o passar do tempo, a humanidade se desenvolveu, ocorreram várias descobertas e inventos e, assim, com novos recursos, o homem passou a registrar e a controlar cada vez mais os aspectos de sua vida, como a contagem de animais que possuía, suas propriedades, formas de renda, etc. (GEORGE JÚNIOR, 1972). Dessas atividades de controle resultaram documentos.

Além desses documentos de controle, o homem desenvolveu documentos ligados à criação artística e às crenças religiosas, ademais daqueles que registravam os resultados de suas pesquisas e estudos científicos. Os 
materiais criados ao longo dos séculos - entre eles destacando-se os livros, jornais, periódicos, quadros, esculturas, objetos, documentos de controle, fotografias -, precisaram ser organizados e guardados. A relação do homem com esses vários tipos de materiais, ajuda-o a obter as informações necessárias ao seu trabalho e às diversas atividades do seu dia-a-dia, constituindo-se, ainda, em formas de entretenimento (no caso da literatura e das demais artes).

Nesse contexto surge a figura da pessoa que guarda, organiza, que cuida da classificação desses materiais e de sua recuperação. Em relação à cultura, percebe-se que é forte o vínculo entre esta e o profissional que trabalha com a informação. Assim, a função do organizador da informação registrada remonta ao aparecimento dos primeiros documentos, os quais tinham como suporte as tábuas de argila. Kobashi (1996), estudando as várias formas de representação da informação, ao longo da história, comenta que atividades para organização e representação de informações eram praticadas desde o segundo milênio a.C. Destaca ainda que os documentos mesopotâmicos da época das cidades-Estado já apresentavam uma forma de tratamento documentário: "as obras cunhadas em tábuas de argila eram protegidas por uma espécie de envelopes, sobre os quais se transcreviam informações que cumpriam função semelhante à dos modernos resumos (fornecer informação concisa sobre o documento original)." (KOBASHI, 1996, p.5).

Tempos depois, foram criados os manuscritos, que tiveram como suporte o papiro e o pergaminho, e depois evoluíram para o livro em rolo (volumen) e o livro em cadernos (codex) (CHARTIER, 1994), além de materiais tridimensionais, mapas e, nos dias atuais, os documentos eletrônicos.

Com o crescimento da produção de informações registradas, foi preciso que as formas de organização também se desenvol- vessem, visando dar conta de uma quantidade cada vez maior de informações, registradas nos mais variados suportes. Surgiram também as instituições criadas com o objetivo de armazenar e organizar informações para sua posterior recuperação e uso, destacando-se entre elas as bibliotecas.

Recorre-se a McGarry (1999, p.111) para confirmar que "as bibliotecas, em seu sentido mais amplo, existem há quase tanto tempo quanto os próprios registros escritos". A criação dessas instituições está ligada ao instinto de preservação do homem e à sua paixão por colecionar, pois "qualquer que seja a sua forma externa, a essência de uma biblioteca é uma coleção de materiais organizados para uso." (McGARRY, 1999, p.111, grifos do autor). Nesse sentido, Oliveira (1983) considera que a organização de documentos passou de um comportamento individual para uma necessidade da sociedade.

Entre as mais antigas instituições merecem destaque: a biblioteca do templo de Ramsés, em Tebas, que possuía um grande acervo, mas, com acesso restrito à casta sacerdotal de escribas e autoridades; as bibliotecas da Assíria e da Babilônia, que tinham caráter governamental e forneciam informações visando estabelecer a ordem (McGARRY, 1999); a biblioteca de Pérgamo, fundada por Átalo I e legada aos romanos por Átalo III em 133 a.C., abrigou cerca de 200 mil pergaminhos no século I a.C., e sua coleção de obras somente era inferior à da biblioteca de Alexandria (NOVA..., 1999). Nesta mesma biblioteca ocorreu a introdução do conceito de autor como ponto de acesso a uma obra (MEY, 1995); a biblioteca de Nínive, na Mesopotâmia, que possuía perto de 20 mil obras dos mais variados assuntos, como magia, religião, história e astrologia, além de catálogos de plantas e animais gravados em placas de argila (MELLO, 1979); e, por último, talvez uma das mais comentadas bibliotecas em todo o mundo: a de Alexandria. 
Devido ao seu tamanho e aos desastres que se abateram sobre ela até a sua destruição final, por volta de 640 d.C., a biblioteca de Alexandria conquistou reconhecimento e fama. Ela foi fundada pelos governantes gregos do Egito, da dinastia dos Ptolomeus (McGARRY, 1999). O sonho dos bibliotecários dessa instituição era reunir em seu acervo a totalidade da literatura existente, ou segundo Cânfora (1996, p.24), "recolher em Alexandria os livros de todos os povos da terra."

Os exemplares eram arrumados em ordem sistemática. Os bibliotecários tinham a preocupação de manter as coleções completas e restaurar as obras defeituosas. Destacam-se ainda, nessa instituição, os primeiros passos dados para o estabelecimento de uma política de formação de acervos, através de negociações com autores, comerciantes, colecionadores, além da prática de copiar os livros que estivessem sendo transportados nos navios que aportavam em Alexandria (McGARRY, 1999). Essa prática ficou conhecida como "o fundo dos navios" (CÂNFORA, 1996; BATTLES, 2003). Mello (1979) narra outro fato interessante em relação a essa biblioteca: segundo esse autor, Ptolomeu pedia emprestado aos gregos obras para serem copiadas e devolvia-lhes as cópias, ficando em Alexandria as originais.

No auge de seu desenvolvimento, a biblioteca de Alexandria chegou a possuir perto de meio milhão de rolos de papiros; McGarry (1999, p.112) comenta que essa instituição conseguiu constituir-se em uma "combinação de centro de pesquisas, editora, instituto de estudos lingüísticos, museu e repositório cultural."

Por um longo período, a imagem dos profissionais que exerciam a função de bibliotecários, ligados à organização e representação de informações registradas, era a de eruditos da época. Shera (1980, p.93) ressalta que, desde o tempo de Ptolomeu, "o bibliófilo dominou a profissão até o início do século XIX", tendo conhecimentos em variadas áreas, como demonstra Fonseca (1992, p.104):

Calímaco de Cirene (c. 305 a.C.-c. 240), um dos mais representativos poetas da erudita e sofisticada escola de Alexandria, foi quem organizou o catálogo da biblioteca; Zenódoto de Éfeso (fl. c. 280 a.C.), notável gramático, responsável pela primeira edição crítica de Homero e pela Teogonia de Hesíodo, foi diretor da biblioteca; Aristófanes de Bizâncio (c. 257-180 a.C.), organizou edições de Homero, Hesíodo, Píndaro, Eurípides, Aristófanes, Anacreonte, foi bibliotecário-chefe em cerca de 195 a.C.; Aristarco de Samotrácia (c. 217-147 a.C.), discípulo do precedente, com ele colaborou na edição de autores gregos, tendo sido bibliotecário-chefe em 153.

Nessa época, uma obra poderia se constituir de vários rolos de papiro ${ }^{4}$, acarretando dificuldades para sua consulta. Assim, para as obras muito extensas, os profissionais resumiam o conteúdo dos rolos, anotavam em pequenas etiquetas de pergaminho e afixavam-nas nos rolos para facilitar a identificação nas prateleiras da biblioteca (SMIT, 1996).

De acordo com Mello (1979), a primeira intenção de criação de uma biblioteca de acesso público apareceu com Júlio César, sendo concretizada tempos depois com o orador Asino Pólio, em 39 a.C., que a estabeleceu no átrio do templo romano da Liberdade. Ainda em Roma, merecem destaque às bibliotecas de Ulpiano, fundada por Trajano, e a Palatina, ambas do século IV.

A partir das informações referentes às bibliotecas antigas podem-se ressaltar as primeiras atividades desenvolvidas pelos organizadores da informação: serviços de aquisição

\footnotetext{
${ }^{4}$ Por exemplo, a obra Pinakes, de Calímaco, ocupava 120 rolos e tratava-se de uma bibliografia crítica que catalogava toda a vasta coleção de literatura grega guardada em Alexandria (SMIT, 1996; BATTLES, 2003).
} 
de materiais, restauração de obras, disposição organizada de documentos nas estantes, indexação - como "processo de condensação de conteúdos de textos." (KOBASHI, 1996, p.11) - de materiais para sua recuperação.

Vale destacar o comentário de Mello (1979) sobre os povos antigos, como os assírios e os egípcios, para os quais os conceitos de biblioteca e de arquivo se confundiam. $\mathrm{O}$ autor ressalta que a maioria das bibliotecas da Antigüidade tinha o acesso restrito, não tendo por finalidade o uso público; em relação a esse limitado acesso de usuários, destaca-se o fato de que, naquele período, as habilidades de leitura e de escrita estavam restritas a uma parcela muito pequena da população.

Na Idade Média, período em que a religião era dominante, existiam os scriptoria monásticos, onde a atividade mais freqüente era a cópia de textos. Smit (1996) ressalta mais uma iniciativa dos monges copistas, visando à representação de informações: os copistas, ao transcrever os manuscritos, freqüentemente, anotavam na margem uma informação que resumia o conteúdo da página: a marginália.

Mello (1979, p.209) comenta que, nesse período, devido ao poder político da Inquisição, obras consideradas pagãs e perigosas, principalmente as da Antigüidade, eram incineradas, e a biblioteca tinha caráter sagrado, sendo "um tesouro de um mosteiro". Fonseca (1979) acrescenta que os acervos das bibliotecas medievais formavam-se a partir de uma mistura de textos litúrgicos e teológicos, obras didáticas para o ensino de latim e, em alguns casos, obras clássicas.

No século VIII foi criada uma das primeiras listas de obras de bibliotecas medievais, provavelmente um inventário do acervo, contendo apenas título e, por vezes, nome do autor, mas sem ordem visível (talvez a ordem das estantes). No ano de 1247, houve um curioso acréscimo feito ao registro dos livros na lista da biblioteca de Glastonbury, na Inglaterra: "inúteis", "legíveis", "velhos" e "bons", provavelmente se reportando às condições do livro (MEY, 1995).

Mey (1995) observa que no século XV surgem, pela primeira vez, as remissivas - registros que remetem a outros registros ou obras -, ainda que de forma primitiva, no catálogo compilado por Amplonius Ratnick de Berka, entre 1410 e 1412. No final desse século há um avanço importante: Johann Tritheim, bibliógrafo e bibliotecário alemão, compila uma bibliografia, apresentada em ordem cronológica e incluindo, pela primeira vez, em apêndice, um índice alfabético de autores. De acordo com Mello (1979, p.212), já no século XV, as bibliotecas vão deixando de ser apenas um "depósito de livros" para se transformarem em instituições modelares, que possuíam regulamentos disciplinares para seu uso.

Ainda na Idade Média se desenvolvem as bibliotecas universitárias, como a de Coimbra, em 1536; as nacionais, como a de Paris, em 1595; e as públicas, como as de Viena, Mogúncia, Lyon, Berna e outras (BOTTENTUIT; CASTRO, 2000). O estudo de Burke (2003, p.44) sobre história social do conhecimento, confirma que, juntamente com o aparecimento das universidades, outras instituições começaram a ser fundadas - muitas vezes dentro delas próprias -, como "jardins botânicos, anfiteatros de anatomia, laboratórios e observatórios", as quais, segundo Burke, podiam ser consideradas "ilhas de inovação dentro de estruturas mais tradicionais".

\section{As universidades, a imprensa e a necessidade da organização dos acervos}

Com a criação das primeiras universidades instauram-se alguns problemas: a) a necessidade de livros para milhares de estudantes: o processo de cópia manuscrita de obras, por ser muito lento, não poderia dar conta da demanda; b) o acesso aos materiais: tanto nas instituições monásticas, como nas 
acadêmicas, o acervo era dividido em duas partes - os livros mais consultados eram acorrentados na biblioteca principal, e os disponíveis para empréstimo eram guardados numa sala separada (McGARRY, 1999). Fazia-se necessária, portanto, a adoção de novas maneiras de disponibilizar as informações aos usuários.

Entende-se que, com a criação das universidades, e, em conseqüência, das bibliotecas universitárias, os usuários passaram a ficar cada vez mais exigentes quanto à organização e disponibilidade dos conhecimentos registrados.

A partir do desenvolvimento da imprensa de tipos móveis, em meados do século XV, por Gutenberg (1397-1468), acentuou-se o aumento do número de publicações. Instituiu-se o processo editorial e as publicações tornaram-se produtos industriais, obedecendo às normas técnicas da época (FONSECA, 1992). A invenção da imprensa aparece como um marco, segundo Burke (2003, p.127), pois, a partir dela, os documentos manuscritos foram separados dos impressos e organizados como um tipo particular, ocupando uma parte especial das bibliotecas ou, em alguns casos, um prédio próprio. Apesar de existirem obras científicas em formato manuscrito, de períodos anteriores (que ficaram nas bibliotecas), grande parte desses documentos continha informações do Estado, da Igreja ou de propriedades particulares (o que anteriormente chamou-se de documentos de controle, ou documentos administrativos). Essas coleções de documentos passaram a constituir o acervo dos arquivos, sendo os arquivistas os "guardiães especiais" desses materiais. Entretanto, existem registros que confirmam a atuação de bibliotecários nos primeiros arquivos, destacando-se os da Igreja em geral (dioceses, por exemplo) e do Vaticano.

Burke (2003, p.56) acrescenta que, após a invenção da imprensa, as bibliotecas, de maneira geral, aumentaram em importância e passaram a ser "centros de estudos, locais de sociabilidade culta e de troca de informações e idéias, além de serem lugares de leitura", e que, nesse momento, a exigência de silêncio nas bibliotecas era inimaginável, pois as mesmas se constituíam como locais para a discussão: portanto, servindo a uma combinação entre a comunicação oral e a impressa.

Ressalta-se a visão do clérigo escocês John Durie segundo a qual, os bibliotecários deveriam ser "agentes para o progresso do saber universal." (WEBSTER citado por BURKE, 2003, p.56). O mesmo clérigo foi autor de um curto tratado sobre a função de bibliotecário, em que argumenta que "um bibliotecário de universidade deveria ser obrigado a 'prestar contas' anuais de seu 'lucro no ofício', em outras palavras, o aumento das aquisições, descritas como o 'acervo de conhecimento'." (WEBSTER citado por BURKE, 2003, p.105).

Os anos de 1560 e 1595 são marcos do surgimento dos primeiros códigos de catalogação, pelas iniciativas de Trefler e Maunsell: Florian Trefler, monge beneditino, publicou um tratado sobre a manutenção de uma biblioteca, desenvolvendo, também, um sistema de classificação. O livreiro inglês Andrew Maunsell compilou um catálogo dos livros ingleses impressos, determinando, no prefácio, as regras para o registro das obras. Maunsell preconizou a entrada dos nomes pessoais pelo sobrenome e, para obras anônimas, usou o título ou assunto e às vezes ambos. Estabeleceu a entrada uniforme para a Bíblia e defendeu a idéia de que um livro devia ser encontrado tanto pelo sobrenome do autor, como pelo assunto e pelo tradutor. Incluiu em seus registros o tradutor, impressor ou pessoa para quem o livro foi impresso, data e número do volume (MEY, 1995). Segundo Burke (2003, p.88), o catálogo da Bodleian Library, em Oxford, "publicado em 1605, separava os livros em quatro grupos principais - artes, teologia, direito e medicina - com um índice geral de autores e índices especiais de comentadores de Aristóteles e da Bíblia". 
Vale destacar ainda o nome do médico Gabriel Naudé (1600-1653), considerado o primeiro teórico da moderna organização de bibliotecas; Naudé organizou a mais antiga biblioteca pública de Paris, a biblioteca do cardeal Mazarin, hoje a Bibliothèque Mazarine, aberta ao público em 1643, e que, dez anos depois, possuía cerca de 40 mil volumes (NOVA..., 1999). Fonseca (1979) aponta a obra de Naudé, Advis pour dresser une bibliothèque, publicada em 1627, como o primeiro livro de biblioteconomia, o qual foi traduzido para vários idiomas e influenciou o contexto da época.

Ainda em relação ao século XVII, Burke (2003, p.44) destaca a formação de "gabinetes de curiosidades", montados nas casas de filósofos e estudiosos da época, e contendo materiais variados como "pedras, conchas ou animais exóticos (crocodilos, por exemplo)", entre outros materiais. Tais "gabinetes" podem ser considerados uma primeira forma do que veio a constituir os museus modernos. Segundo Burke, o entendimento dos estudiosos e pesquisadores dos dias atuais, em relação às pinturas e registros gráficos desse período, coloca os museus como instituições que tinham o objetivo principal de "dar aos espectadores uma impressão não só de abundância mas de heterogeneidade" (BURKE, 2003, p.100), pois muitos desses gabinetes continham, muitas vezes lado a lado,

[...] peixe empalhado pendurado no teto (junto com um pequeno urso), e galhadas de veado exibidos na parede junto com chifres de beber. O catálogo revela um conjunto ainda mais amplo de objetos, incluindo uma múmia egípcia, um antigo broche romano, dinheiro de Java, manuscritos da Etiópia e do Japão e cachimbos do Brasil, além de muitas antigüidades nórdicas - lanças da Groenlândia, um arco da Lapônia, esquis da Finlândia e um antigo escudo da Noruega. (BURKE, 2003, p.100).
Mesmo mesclando os mais variados tipos de objetos, Burke (2003, p.100) considera que existia, na forma de disposição dos materiais, um desejo de classificar, como demonstram as pesquisas sobre o museu de Ole Worm (1588-1654), polimata dinamarquês (BURKE, 2003, p.241), que incluía os materiais em caixas rotuladas como "Metal", "Pedra", "Madeira", "Conchas", "Ervas", "Raízes”, entre outras.

Coleções de materiais como a de Worm, foram organizadas e publicadas como livros (os chamados "museus em papel") nesse mesmo período, pois se entendia que o museu era um "microcosmo, um universo em miniatura" (BURKE, 2003, p.102) e, a partir dele, as pessoas poderiam se instruir e entender aspectos da vida em diferentes partes do mundo. As moedas, por exemplo, poderiam ser organizadas segundo várias categorias, como de imperadores, de províncias, de deuses, de virtudes, de guerras, de jogos, etc., ou simplesmente em ordem cronológica. Outro ponto destacado pelo autor em relação à criação dos museus é o aparecimento de uma diversidade de materiais provindos dos novos continentes, muitas vezes diferentes daqueles materiais aos que os europeus estavam acostumados (BURKE, 2003). Essa idéia de novos horizontes, de diversidade e de crescimento, indubitavelmente se refletia na vida cultural das pessoas.

A partir de 1609, de acordo com Burke (2003), governos de países como a Inglaterra, a Espanha e a França, começaram a atribuir nomeações oficiais aos profissionais organizadores, que eram chamados de arquivistas ou curadores de documentos. Muitos desses profissionais eram estudiosos e eruditos que desempenhavam, primeiramente em tempo parcial e depois, em tempo integral, atividades de guarda, organização e indexação de documentos.

Burke comenta que a criação dos arquivos, inicialmente, não teve o caráter de servir à pesquisa e aos pesquisadores (embora mais 
tarde esses documentos tenham sido muito utilizados para esse fim), mas para facilitar a administração dos reis e dos governantes e que "o princípio do acesso público aos arquivos só foi proclamado com a Revolução Francesa" (BURKE, 2003, p.129).

O século XVIII é marcado pelo crescimento substancial das bibliotecas na Europa, gerado pelo desenvolvimento da pesquisa científica e atividades de estudo. Um acontecimento que merece destaque ocorreu durante a Revolução Francesa, quando as bibliotecas dos nobres foram confiscadas e transformadas em bibliotecas de uso público, levando assim o governo da Revolução a estabelecer, em 1791, normas para sua organização, dando origem ao primeiro código nacional de catalogação. Data desse período, o uso de catálogos em fichas (MEY, 1995).

Martins (1996, p.323) considera que, do século XVI até o XVIII, as bibliotecas sofreram um processo gradativo de mudança, caracterizado por quatro fatores principais: "1) a laicização; 2) democratização; 3) especialização; 4) socialização". A laicização é a libertação da pressão religiosa, caracterizada pelo acesso limitado, tanto em relação aos prédios das bibliotecas quanto aos seus materiais de consulta (livros, periódicos ou quaisquer outros documentos); os livros, especialmente, perdem o caráter de objetos sagrados e secretos, e passam a ser vistos como instrumentos de trabalho.

Em relação à democratização, essas instituições vêm a adotar uma postura, em relação a todos os usuários, no sentido de que houvesse uma "ascensão do homem comum aos privilégios que antes estavam reservados apenas a uma minoria." (MARTINS, 1996, p.324). A democratização levou à especialização, pois as necessidades das pessoas foram se tornando cada vez mais variadas, sendo impossível uma instituição conseguir abarcar, em seu acervo, todos os assuntos. Primeiro, surgiram as coleções especializadas; mais tarde, constituíram-se as bibliotecas especializadas; uma primeira divisão estabelecida foi entre as bibliotecas de conservação (como as de obras raras) e as de consumo, que se prestavam ao uso coletivo, centrando-se nas necessidades mais simples de informação (como as públicas). Em seguida, aparecem as bibliotecas universitárias, militares, industriais, escolares, médicas, e as jurídicas, entre tantas outras.

A socialização é o último fator destacado, e refere-se à preocupação das instituições em atrair um número cada vez maior de usuários, buscando satisfazer seus desejos e necessidades informacionais (MARTINS, 1996).

Importantes avanços aconteceram no século XIX, com a criação da Classificação Decimal de Dewey (CDD), criada por Melvil Dewey, bibliotecário norte-americano, em 1876. Este é um sistema de classificação decimal para catalogar livros e documentos, que passou a ser adotado por inúmeras bibliotecas em todo o mundo (NOVA..., 1999). Ainda no mesmo ano, Charles Ami Cutter publicou suas Rules for a dictionary catalogue (Regras para um catálogo dicionário) com um esquema de classificação e uma tabela representativa de sobrenomes, que são utilizados até os dias atuais (MEY, 1995).

Em 1895, o advogado belga Paul Otlet fundou o Instituto Internacional de Bibliografia, juntamente com Henri-Marie La Fontaine. Juntos desenvolveram, no final do século XIX, a Classificação Decimal Universal (CDU), um tratado para organização e indexação de acervos (FONSECA, 1992; NOVA..., 1999).

Ainda no século XIX, marcado pela revolução industrial e pelo desenvolvimento tecnológico, constata-se um vertiginoso aumento na produção editorial. Começam a aparecer publicações sistemáticas, como os primeiros índices cumulativos. Neste período, nasceu a idéia de fazer-se um Controle Bibliográfico Universal (CBU) e o Instituto Internacional de Bibliografia se propôs a fazer um registro (uma "ficha") para cada obra publicada, de forma a viabilizar o CBU. 
Porém, logo verificou-se que o CBU não era um projeto possível, e sim, um sonho grande demais.

García Gutiérrez (1999) entende a iniciativa do CBU como um marco histórico que impôs a existência de uma área preocupada em estabelecer a organização de todo o repertório bibliográfico do mundo. Mesmo não tendo continuidade, a partir daí tomou-se consciência de que a descrição dos documentos, feita com uniformidade e consistência, era importante e não se podia mais trabalhar de forma individualizada, pois almejava-se a troca ampla de informações (SMIT, 1996).

Como alternativa para o controle bibliográfico, porém de maneira mais restrita, aparece o depósito legal, uma lei que obriga os editores a depositarem um exemplar de cada publicação nas bibliotecas designadas como depositárias (McGARRY, 1999). No Brasil, a Biblioteca Nacional, no Rio de Janeiro, ficou responsável pelo depósito legal e controle da produção bibliográfica nacional. Segundo Martins (1996), que em sua obra transcreve a lei do depósito legal brasileira, de 20 de dezembro de 1907, ficam obrigadas as editoras a depositarem não só livros, mas periódicos, folhetos, jornais, obras musicais, mapas, plantas e estampas chegando até aos selos, medalhas e outras espécies de materiais numismáticos.

Segundo Martins (1996), até a Renascença existiam profissionais que organizavam os materiais. Do século XV ao século XIX o bibliotecário era um profissional "contratado por instituições particulares, sem formação especializada, quase sempre um erudito ou um escritor". (MARTINS, 1996, p.332). Para esse autor, a profissão de bibliotecário, como atividade especializada, só apareceu no século XIX, sendo reconhecida pelo Estado como uma profissão socialmente indispensável. Mesmo com a profissão instituída, os eruditos ainda ocuparam posições de bibliotecários, muitas vezes sem especializações técnicas, até o aparecimento dos cursos de biblioteconomia.
Também é do século XIX a criação da Library of Congress (LC), fundada em 1800 e sediada em Washington. Esta desempenha a função de biblioteca nacional dos Estados Unidos, principalmente servindo de fonte de informações ao Congresso e a outros órgãos oficiais desse país (FONSECA, 1979; FONSECA, 1992; NOVA..., 1999).

No século $X X$, a comunicação humana expande-se ainda mais com o desenvolvimento das Tecnologias de Informação e Comunicação (TIC). A primeira aplicação do processamento de dados nas bibliotecas se deu em 1935, na University of Texase, em 1941, na Boston Public Library, na qual se introduziu o uso dos cartões perfurados para o controle de empréstimo de livros (FONSECA, 1979).

No Brasil, no campo da organização de informações destaca-se, com o aparecimento dos computadores - na década de 1960 - a automação de serviços de documentação e, por intermédio dela, uma tentativa de padronização do processamento das informações. Nesse período também começaram as primeiras pesquisas sobre indexação automática, ou seja, o tratamento de conteúdo feito por computador (SMIT, 1996).

De acordo com Souza et al. (2000), o desenvolvimento da tecnologia de redes eletrônicas intensificou o fenômeno da explosão de documentos eletrônicos, ocasionando o aumento do volume de informações disponíveis. Neste contexto, foi desenvolvido o conceito de metadado - "dado sobre o dado" -, isto é, a descrição do documento eletrônico visando facilitar sua recuperação nos sistemas de busca e recuperação. Nesta área, destaca-se o formato MARC (MAchine Readable Cataloging) para descrição de informações bibliográficas, desenvolvido desde 1968 pela Library of Congress e difundido por todo o mundo (FONSECA, 1979).

Como destacam Smit e Barreto (2002), de nada adianta haver um grande estoque de informações armazenadas, tanto em bases de 
dados como em bibliotecas, arquivos, museus ou quaisquer outras instituições, sem que exista uma comunicação consentida entre a fonte (os estoques) e o receptor, pois esses estoques de informação não têm compromisso direto e final com a produção de conhecimento. É de suma importância o tratamento desses estoques para que as informações neles contidas possam ser bem exploradas e aproveitadas pela coletividade. Nesse sentido, destaca-se a posição do organizador e difusor da informação: o indivíduo responsável pelo seu tratamento, com vistas ao acesso e ao compartilhamento das informações. Além disso, este trabalho apresenta um aspecto de suma responsabilidade, pois requer a adequação das informações aos diferentes tipos de usuários, os quais apresentam variados graus de instrução, diferentes níveis de renda, professam diversas religiões, e pertencem a diversas raças - fatores que interferem no seu acesso à informação.

Até aqui, pretendeu-se traçar um breve histórico, ressaltando o desenvolvimento das várias formas de registro da informação como motivo do nascimento da função do organizador de informação. Os dados até aqui apresentados permitem afirmar que, até o início do século $X X$, a profissão de bibliotecário tinha um caráter elitista, tanto pelo alto nível de conhecimento e erudição dos profissionais, quanto pelo fato de a instituição biblioteca atender quase exclusivamente às pessoas com alto nível educacional. A imagem do profissional estava ligada à biblioteca, na condição de "aposento que ou lugar onde se colocam livros; galeria, construção cheia de livros" (CHARTIER, 1994, p.70), mesmo que nela constassem outros tipos de materiais.

\section{Organizadores e difusores da informação: o bibliotecário em questão}

A partir da exposição anterior, a respeito dos diferentes tipos de materiais que foram criados ao longo da história pela humanidade e da necessidade de profissionais que cuidassem de sua organização e disponibilização com o objetivo de acessar esses materiais no futuro, passa-se agora a abordar especificamente as características de alguns desses profissionais: o bibliotecário e o documentalista.

Novamente recorrendo a McGarry (1999, p.111), lembramos que "as bibliotecas, em seu sentido mais amplo, existem há quase tanto tempo quanto os próprios registros escritos"; entende-se que elas foram as primeiras instituições criadas com a intenção de organizar a informação registrada e que as iniciativas destacadas no tópico anterior, somadas a outros conhecimentos que não foram citados, formaram o arcabouço de conhecimentos da Biblioteconomia.

De acordo com Fonseca (1992, p.59), a origem da palavra biblioteca vem do grego bibliothéke, em que biblion significa livro e théke denota "qualquer estrutura ou invólucro protetor como cofre, estojo, caixa, estante e edifício". Daí sua ligação tão fortemente estabelecida, até os dias atuais, com o livro como portador de informação.

O profissional que atua nas bibliotecas é o bibliotecário, desde que seja diplomado em curso de biblioteconomia (FONSECA, 1992, p.101). A formação do bibliotecário teve duas correntes principais: uma linha humanista proposta pela École Nationale des Chartes, fundada em Paris, em 1821, e outra, de caráter tecnicista, surgida em 1887, nos Estados Unidos, com a School of Library Economy, fundada por Melvil Dewey na Columbia University em Nova York (BOTTENTUIT; CASTRO, 2000). Martins (1996) ressalta que o ensino da escola francesa era o mesmo para bibliotecários, arquivistas-paleógrafos e arqueólogos.

O Brasil sofreu influência dessas duas escolas, prevalecendo, no entanto, o modelo americano. De acordo com Bottentuit e Castro (2000), por volta de 1940, duas escolas funcionavam no país: uma em São Paulo, inspirada nos 
métodos norte-americanos e uma no Rio de Janeiro, subordinada à Biblioteca Nacional, que seguia a linha européia.

O curso de Biblioteconomia da Biblioteca Nacional sofreu reformas, sob a orientação do escritor Josué Montello. Montello, citado por Bottentuit e Castro (2000, p.35) relata:

[...] fiz em 1944 a grande transformação e atualização do curso que ainda era muito voltado para o saber humanístico. Eu procurei dar a esse curso uma orientação técnica moderna, resultado dos trabalhos técnicos da Biblioteconomia. E fui encarregado pelo Diretor da Biblioteca, para dirigir esses cursos. E a direção que dei, era eminentemente atualizada com o que se estava fazendo em última palavra nas escolas americanas.

Martins (1996, p.332) ressalta, como resultado da adoção da linha norte-americana, que a profissão de bibliotecário tomou, ao longo do tempo, o caráter de "técnico puro". O autor ainda discute "a estreiteza mental que decorre, freqüentemente demais, da especialização" e como ponto positivo destaca "a organização racional do trabalho". Na verdade, Martins (1996) coloca como ideal uma combinação das duas correntes, pois segundo ele, não se pode admitir um bibliotecário erudito que não domine as técnicas biblioteconômicas, porém, um "bibliotecário exclusivamente preso aos números da tabela de Dewey é também inferior ao que a biblioteca representa como cultura e às próprias funções que deve desempenhar." (MARTINS, 1996, p.338).

Ferreira, citada por Souza (1994, p.12), indica que, desde 1973, quando da promoção de um seminário pela Universidade Federal de Minas Gerais (UFMG) sobre a "Formação do bibliotecário face às exigências profissionais da atualidade", se discutiam problemas relaciona- dos à escolha do curso de Biblioteconomia; Ferreira enfatiza que tal escolha se devia mais a fatores secundários como a "menor duração do curso, influência de amigos, gosto por livros, do que a uma decisão consciente, por vocação".

Dias, citado por Oliveira (1983, p.6), destacava a preocupação com a especialização técnica excessiva dos profissionais, comentando serem eles "pouco familiarizados com os problemas da cultura e da pesquisa". Reforçando este ponto de vista, Lorusso, citada por Souza (1994, p.5), ao discutir a posição das escolas de Biblioteconomia em 1992, aponta:

\section{[...] já é fato consumado que o currículo mostra-se incompatível com a reali- dade cotidiana, quer pela terminologia, quer pela continuidade do currículo anterior em termos de mentalidade e conteúdos. Em muitas escolas, a terminologia mudou, mas o conteúdo permaneceu. Uma roupa nova num conteúdo antigo. E o que é pior: a manutenção dos mesmos hábitos ou vícios preconizados.}

Recentemente, Rodrigues (2002), em estudo sobre a formação dos Profissionais da Informação (PI) nesse novo ambiente, ainda ressalta o caráter técnico da formação, mas já constata um movimento que tenta minimizar e/ou romper com a massificação técnica dos profissionais, evidenciando a importância da pesquisa nas universidades, com o intuito de enriquecer o perfil dos profissionais por ela formados.

A Documentação ${ }^{5}$ nasce pela iniciativa de Otlet e de La Fontaine, caracterizada como "processo que permite reunir, classificar e difundir todos os documentos de toda a espécie, relativos a todos os setores da atividade humana." (SHERA, 1980, p.95). Segundo Buckland (1991), o termo documento ou unidade documentária foi utilizado como um termo genérico que denotava

\footnotetext{
5 Existiam duas linhas de formação profissional: uma, na Europa, formando profissionais chamados documentalistas; outra, nos Estados Unidos e América Latina, formando bibliotecários.
} 
coisas informativas. Briet, citada por Buckland (1991, p.355), definiu documento como "qualquer indicação concreta ou simbólica, preservada ou registrada, para reconstruir ou para comprovar um fenômeno, seja físico ou mental". Por essa razão, documento poderia ser desde um manuscrito até uma peça de museu. Robredo e Cunha (1994, p.3) entendem que o termo documento foi ampliado e passou a englobar "todo tipo de suporte físico da informação, que permita o seu armazenamento". Neste sentido, passou a incluir também os cartões perfurados do início da informática, as fitas magnéticas gravadas e os programas de computador.

O caráter de erudição do profissional ligado à organização da informação e do conhecimento registrado foi perdido, segundo García Gutiérrez (1999, p.36), em decorrência do contexto social-histórico em que foram estabelecidas essas profissões, citando como exemplo o documentalista. O autor afirma que a "Informação/Documentação deve ser observada no marco geral dos fenômenos que dizem respeito à Cultura e à Comunicação de massas", surgindo como uma "ferramenta fundamental de instrução social." (GARCÍA GUTIÉRREZ, 1999). Portanto, seu profissional, o documentalista, se instituiu com um forte caráter social.

Entretanto, o mesmo autor critica a posição dos que acreditam ser esse profissional "uma espécie de representante e benfeitor dos desprotegidos usuários que desejam informarse para produzir mais informação." (GARCíA GUTIÉRREZ, 1999, p.37). Ressalta, ainda, que o documentalista de meios de comunicação, de maneira geral, possuía cultura média e desenvolvia um trabalho rotineiro e impessoal, com pouco reconhecimento e prestígio social, passando esse mesmo profissional a contemplar a informação que manuseava como uma verdadeira massa disforme, fora de contexto (GARCíA GUTIÉRREZ, 1999). Para García Gutiérrez (1999), faltou a esse profissional uma postura crítica e subentende-se que essa falta deveu-se à sua pouca instrução.
Shera (1980) acrescenta que a mudança de foco na orientação, da preservação da informação, para o usuário, já era latente na conferência de bibliotecários que se realizou em 1853, a partir do enfoque no serviço ao público (grifos nossos). Pode-se, a partir das colocações de García Gutiérrez e de Shera, já citadas, analisar alguns pontos:

1) inicialmente, à época das primeiras universidades, os bibliófilos (ou bibliotecários eruditos) atuavam em bibliotecas tendo contato com um número reduzido de usuários; portanto, tinham mais tempo para estudar e conhecer seu acervo, que crescia em proporções bem menores do que as de hoje;

2) os bibliotecários eruditos, em sua maioria, eram formados primeiramente em outra área do conhecimento, e a partir daí se dispunham a organizar as bibliotecas; o que leva à discussão sobre a Biblioteconomia como área que deve ser estudada em nível de pós-graduação - Cunha (2000, p.73), estudando a formação dos PI na França, destaca a opinião emitida pela associação francesa dos profissionais de informação e documentação, segundo a qual "a dupla formação é indispensável para trabalhar a informação", não sendo possível "tratar a informação corretamente sem ser especialista do assunto tratado";

3) as linhas americana e francesa valorizavam diferentemente a técnica e a erudição. A partir da implementação dos cursos de Biblioteconomia, entende-se que, dependendo da linha escolhida - e no Brasil sabe-se que predominou a norte-americana -, a classe profissional, de forma geral, foi influenciada e se estabeleceu dentro dessa linha, com o predomínio da função técnica.

Martins (1996, p.335) entende que a ênfase na técnica, em detrimento da cultura geral, aliada ao crescente aumento de materiais de todas as espécies - explosão informacional -, foi responsável pelo fato de a categoria de bibliotecários passar a encarar os materiais como "uma carga e um estorvo". 
O trabalho de Oliveira (1983) apresenta os pontos-chave responsáveis pela institucionalização da profissão de bibliotecário: a elaboração de um código de ética; a criação de associações profissionais; a elaboração de currículos acadêmicos próprios; o treinamento especializado; o desenvolvimento de um corpo teórico; um volume significativo de publicações; o trabalho ser assegurado pela legislação; o fornecimento de serviços à comunidade; a aceitação, por parte da comunidade, da autoridade desse profissional.

Mesmo com uma profissão instituída, a categoria começou a enfrentar problemas em relação à sua visibilidade, pelos próprios bibliotecários e por outras categorias profissionais. Martins (1996, p.333) apresenta em sua obra uma discussão ocorrida em um congresso de bibliotecários promovido em São Paulo, no ano de 1951, pela Organização das Nações Unidas para a Educação, a Ciência e a Cultura (Unesco), em que se destacavam quatro perfis principais de bibliotecários atuantes na América Latina: o primeiro era formado por pessoas "muito estimáveis, conscienciosas, dignas de confiança e amantes da leitura", porém "sem a menor idéia das técnicas da área"; o segundo, englobava "certo número de mulheres casadas ou de solteironas, também das mais estimáveis, que, por qualquer motivo, tiveram necessidade de ganhar a vida" e que "não passavam de guardiãs de livros" (estereótipo comentado até os dias atuais); o terceiro perfil incluía "'a personalidade em evidência' com todas as qualidades intelectuais, mas sofrendo da moléstia incurável e inconfessável de não ser técnico"; o último, era composto pelos bibliotecários profissionais com formação na área.

A transcrição do trecho acima pretende apenas demonstrar que a discussão em relação à categoria dos bibliotecários não é recente. Para ilustrar ainda mais as discussões, desde tempos passados, ressalta-se a observação de Litton (1976, p.187) alertando sobre a "falta de visão e a pouca ou nula vontade que possuem os bibliotecários de enfrentar os novos e crescentes usos e manifestações da documentação científica".

Oliveira (1983) ressalta largamente os problemas relacionados à prevalente má percepção da profissão, discutidos por diversos autores em vários congressos da área, entre as décadas de 1950 e 1970. Tais problemas são apresentados, a seguir, de forma resumida, acentuando-se a necessidade de mudança nesses aspectos: a mentalidade dos profissionais da área, que deveriam ter maior preocupação com sua realização profissional e mais consciência do seu papel; ausência total de criatividade para a implantação de serviços (por esses profissionais se prenderem muito às técnicas); isolamento dos profissionais (falta de consciência de classe); e visão estereotipada que o público tem dos mesmos (devido ao grande número de mulheres não qualificadas, empregadas na categoria).

Trabalhos mais atuais, como o de Barbosa (1998), ainda discutem a questão da denominação do bibliotecário como resultado da ligação quase que exclusiva aos livros na visão da sociedade em geral. Na realidade, as pessoas consideram que o ambiente da biblioteca é apenas mais um edifício que guarda materiais, desconhecendo que este profissional trabalha com fluxos de informação armazenada. O autor ainda ressalta que "o verdadeiro 'negócio" da biblioteconomia é a informação, e não livros". (BARBOSA, 1998, p.55).

Guimarães (2000) entende que é por meio da melhor formação do profissional da informação que se poderá obter um maior reconhecimento profissional por parte da sociedade; esta melhor formação deve ser promovida através de investimentos das universidades e das instituições formadoras em uma dimensão investigativa, para que dela possam resultar conhecimentos teóricos e práticos (metodologias, aplicações) para que a coletividade possa ver e reconhecer o esforço da área e entender a atuação dos PI. Sem essa 
iniciativa, o autor entende que a formação se vincula basicamente à reprodução de conhecimentos. Smit (2000) corrobora as colocações de Guimarães e opina que a pesquisa - tanto teórica como de aplicação prática - trará progresso para a Ciência da Informação $(\mathrm{Cl})$ como área do conhecimento e, em conseqüência, aos seus profissionais. Cunha, citada em Cunha e Crivellari (2004) entende que, "quanto maior o poder de abstração teórica de uma profissão, mais sólida ela será no espaço social e no sistema profissional".

Acredita-se que, com o passar do tempo, muitas das colocações acima citadas, como a visão estereotipada dos profissionais atuantes nas categorias de bibliotecários e documentalistas, por exemplo, foram sendo cristalizadas e as áreas passaram a incorporar essas posições até os dias de hoje (salvo exceções), levando a outros problemas, como a falta de reconhecimento pelos próprios profissionais e também pela coletividade.

\section{Profissional da Informação: um profissional em busca de identidade}

Como se vem destacando, com a diversidade de materiais e suportes de informação, houve a necessidade de as instituições, e portanto, de seus profissionais, se especializarem. De maneira bem geral, em uma primeira tentativa de divisão, pode-se pensar que museus cuidam de objetos, arquivos guardam documentos de controle ou administrativos, e bibliotecas armazenam informações para estudo, como livros e periódicos. Buckland (1991) corrobora essa divisão com uma similar - bibliotecas lidam com livros; sistemas de informação baseados em computadores manuseiam dados em bits ou bytes; museus manuseiam diretamente objetos, mas assinala que a intenção comum é sempre auxiliar os usuários a se tornarem informados.

Para Smit (2000) as áreas da Biblioteconomia/Documentação, Arquivologia e
Museologia são áreas afins. Grosso modo, apesar de se esperar que as bibliotecas trabalhem basicamente com livros e periódicos, os arquivos, com documentos administrativos e os museus, com objetos, na prática, um arquivo pode possuir livros em seu acervo; uma biblioteca, por sua vez, pode ter uma coleção de fotos ou gravuras, enquanto um museu pode guardar quaisquer tipos de documentos que retratem uma época que se deseja representar, incluindo-se fotos e livros, entre outros materiais, cabendo aos profissionais específicos saber como lidar com eles. Fica claro, portanto, que as três áreas se relacionam, pois trabalham com a informação, possuem estoques de materiais e têm como objetivo comum guardá-los, conservá-los e disponibilizá-los para a presente e as futuras gerações.

Robredo e Cunha (1994) colocam arquivistas, bibliotecários e museólogos como irmãos de profissão, lembrando que, em alguns países, os três formam uma mesma família profissional. Fonseca (1979) destaca uma primeira tentativa de agrupamento entre as áreas de Biblioteconomia, Documentação e Arquivologia com a criação, pela Unesco, em 1948 do Conselho Internacional de Arquivos. Em 1952 foi realizado um evento em Madri, o I Congresso Ibero-Americano de Arquivos, Bibliotecas e Propriedade Intelectual e, em 1972, em Washington, o Seminário Interamericano sobre Integração de Serviços de Informação dos Arquivos, Bibliotecas e Centros de Documentação. Por último destaca-se, em 1974, a realização da Conferência Intergovernamental sobre a Planificação das Infra-Estruturas Nacionais de Documentação, de Bibliotecas e de Arquivos, promovida pela Unesco, em Paris. Essa mobilização ficou conhecida como o pacto entre bibliotecas e arquivos.

O que diferencia os profissionais que atuam nessas áreas? Seria o tipo de material com que trabalham? Mesmo assim, como se demonstrou no parágrafo anterior, cada instituição 
acima citada - arquivo, biblioteca e museu - pode ter em seu acervo documentos e materiais que deveriam, por essa regra de tipo de material, estar em poder de outra instituição. Smit (2000) argumenta que a diferenciação das áreas por tipo de material com que trabalham não é a melhor opção, mas sim a diferenciação pelo uso que se faz da informação veiculada por esse material:

A informação sendo una, "informação" sem outros predicados, é o usuário, em sua busca, e de acordo com suas necessidades, que atribui funções diferenciadas à informação. É nessa acepção que proponho que passemos a entender as expressões "informação arquivística", "informação bibliográfica" e "informação museológica", ou seja, entender que os atributos que especificam o termo-raiz "informação" não designam tipos de documentos mas tipos de utilização da informação. (SMIT, 2000, p.128).

Guimarães (2000), em estudo que tratou da formação dos $\mathrm{PI}$, destacou a iniciativa do Ministério da Educação a respeito da elaboração de diretrizes curriculares nas diversas áreas do conhecimento. Para a comissão de $\mathrm{Cl}$ foram convocados profissionais renomados de diversas universidades; desse encontro surgiu um primeiro delineamento de diretrizes curriculares que abrangessem os cursos de Arquivologia, Biblioteconomia e Museologia, por estas áreas possuírem um núcleo comum de conteúdos, centrados no documento e na informação. Esse autor enfatiza a necessidade de maior diálogo entre essas áreas, para que saibam reconhecer a atuação de cada uma e promovam o respeito dos seus profissionais em relação às outras áreas e à coletividade, além de tratarem do estabelecimento de ações integradas para sua melhor visibilidade.

Existem duas outras áreas que se juntam a essa discussão em relação às definições, a de Documentação e a de Ciência da Informação. De acordo com Fonseca (1992), a Bibliote- conomia tem como objetivo a democratização da cultura por meio das bibliotecas públicas; a preservação e difusão do patrimônio bibliográfico de cada nação, por meio das bibliotecas nacionais e bibliografias nacionais correntes e retrospectivas; o apoio documental ao ensino e à pesquisa oferecidos pelas bibliotecas universitárias. À Documentação compete fornecer resumos de pesquisas, concluídas ou em andamento, por meio de artigos, comunicações a congressos, relatórios, teses, patentes, etc., e, eventualmente, traduções desses documentos, muitos dos quais não impressos. A Ciência da Informação tem como objetivo estudar a gênese, transformação e utilização da informação.

Le Coadic (1997, p.517), trata da Ciência da Informação e suas disciplinas correlatas - Biblioteconomia, Documentação, Arquivística, Museologia e Comunicação - considerando-as práticas empíricas de organização e não, ciências rigorosas (grifos nossos). A comunicação é vista como um contato, uma interação entre pessoas. São tratados os processos de comunicação da informação: os escritos (o artigo, a revista, a literatura) e os orais (contatos, reuniões, congressos).

$\mathrm{A} \mathrm{Cl}$ é uma disciplina relativamente nova, surgida na década de 1950, e que possui grande ligação com as TIC.

[A informação é] o objeto de estudo da Ciência da Informação como campo que se ocupa e se preocupa com os princípios e práticas da criação, organização e distribuição da informação, bem como com o estudo dos fluxos de informação desde sua criação até a sua utilização, e sua transmissão ao receptor em uma variedade de formas, por meio de uma variedade de canais. (SMIT e BARRETO, 2002, p.17, grifos nossos).

Robredo e Cunha (1994, p.5) discutem o caráter interdisciplinar da $\mathrm{Cl}$, defendendo que esta se relaciona com áreas como "as matemá- 
ticas, a lógica, a lingüística, a psicologia, a informática, a pesquisa operacional, a análise de sistemas, as artes gráficas, as comunicações, a biblioteconomia, a administração etc." Ressaltam, ainda, que tanto a biblioteca tradicional quanto a documentação "não são mais do que aplicações particulares da ciência da informação".

No debate sobre a ligação da Biblioteconomia, Documentação e Ciência da Informação existem autores que entendem ser, cada uma dessas áreas, a continuação da outra, caracterizando-as como evolução da mesma disciplina (SHERA, 1980; ALMEIDA JÚNIOR, 2000; HJØRLAND, 2000). Abaixo, alguns pontos que pretendem sustentar essa abordagem:

"Novamente como em Biblioteconomia, a questão não é sobre o campo de atuação, mas sobre paradigmas, fundações teóricas e soluções pragmáticas, e por último, suas conveniências para os problemas humanos de informação". (SARACEVIC, 1995, p.38).

Hjørland (2000, p.509) entende que a Cl é um desenvolvimento, ou uma evolução, da área da Documentação, a qual, por sua vez, e de acordo com o autor, "é um neologismo, isto é, uma nova nomenclatura, desenvolvida primeiramente por Paul Otlet para designar armazenamento e recuperação da informação, serviços primeiros da Biblioteconomia".

É importante destacar os tênues limites entre a Biblioteconomia, a Documentação e a Ciência da Informação. Shera (1980) destaca etapas de um processo, em que a evolução entre as áreas fica quase comprovada:

No entanto, não só se propuseram a fazer um trabalho completo, mas também submeter os materiais bibliográficos a uma análise de conteúdo mais profunda do que a até então feita pelos bibliotecários e, para diferenciar sua atividade da Biblioteconomia, deram-lhe o nome de Documentação. (SHERA, 1980, p.91).
O Quadro 1 mostra algumas definições sobre as áreas mais discutidas, para facilitar o entendimento em relação à confusão instalada, pelos próprios pesquisadores, sobre a atuação de cada área que trabalha com a informação.

Em relação ao exposto no Quadro 1 destacam-se, por exemplo, as definições de Bibliologia de Paul Otlet, de 1934, comparando-a com a de Documentação, de Javier Lasso de la Vega, de 1954: as duas definições partem de uma coleção de materiais, sendo que a primeira se centra nos livros e, a segunda não especifica o tipo de material, mas deduz-se que sejam documentos pelo fato de a definição ser a de Documentação. De acordo com a definição de Briet, citada por Buckland (1991, p.355), e já apresentada anteriormente, entende-se por documento "qualquer indicação concreta ou simbólica, preservada ou registrada, para reconstruir ou para comprovar um fenômeno, seja físico ou mental"; portanto, segundo esse raciocínio, poderiam incluir-se livros à definição de Lasso de la Vega.

Sobre as definições de Ciência da Informação de R.S. Taylor, de 1963, e de Documentação da Federação Internacional de Documentação (FID), de 1971 ressalta-se que ambas se referem à organização e à difusão de informação, não sendo especificado nenhum suporte.

As diferentes definições das áreas se refletiram na nomenclatura de instituições importantes: por exemplo, o Instituto Internacional de Bibliografia, fundado em 1895, em 1931 passou a ser chamado Federação Internacional de Documentação (FID), a partir de 1986 até os dias atuais, é chamado Federação Internacional de Informação e Documentação (FID). Outro exemplo, o American Documentation Institute, fundado com esse nome, passou a chamar-se American Society for Information Science (ASIS) em 1968 (GARCÍA GUTIÉRREZ, 1999) e, a partir de 2000, mudou outra vez seu nome, para American Society for Information Science and Technology (ASIS\&T) 
(AMERICAN..., 2004), destacando-se a influência das TIC. No Brasil, o Instituto Brasileiro de Bibliografia e Documentação (IBBD), criado em 1954, passou a se chamar, a partir de 1976, Instituto Brasileiro de Informação em Ciência e Tecnologia (IBICT) (FONSECA, 1979; 1992). Segundo Fonseca (1992, p.115), "a transfor- mação do IBBD em IBICT corresponde à transição da documentação para a ciência da informação".

A situação é bem complexa. Com cada área mudando de nome seguidamente, os profissionais recebiam distintas denominações em cada uma delas, mesmo que estivessem

Quadro 1. Diferentes definições em relação à organização da informação e suas áreas.

\begin{tabular}{|c|c|c|c|}
\hline Definição & Data & Área & Autor \\
\hline Descrição de livros, coleção, cuidado e administração. & 1934 & Bibliografia & Paul Otlet \\
\hline $\begin{array}{l}\text { Ciência que estuda a produção, conservação, circulação } \\
\text { e uso de documentos. }\end{array}$ & 1934 & Bibliologia & Paul Otlet \\
\hline $\begin{array}{l}\text { Arte de coletar, classificar e fazer acessíveis os } \\
\text { documentos. }\end{array}$ & 1948 & Documentação & S. C. Bradford \\
\hline $\begin{array}{l}\text { Processo de colecionar e classificar por matérias e de } \\
\text { facilitar testemunho aos inventores e descobridores. }\end{array}$ & 1954 & Documentação & Javier Lasso de la Vega \\
\hline $\begin{array}{l}\text { Ciência e prática da elaboração e da organização da } \\
\text { informação em todos os domínios científicos e técnicos. }\end{array}$ & 1959 & Documentação & FID \\
\hline $\begin{array}{l}\text { Ciência que estuda as propriedades das forças que } \\
\text { regem o fluxo e os meios do processo informativo, isto } \\
\text { é, a criação, difusão, coleção, organização, armaze- } \\
\text { namento, busca, interpretação e uso da informação. }\end{array}$ & 1963 & Ciência da Informação & R. S. Taylor \\
\hline $\begin{array}{l}\text { Estudo das propriedades do conhecimento e da transfe- } \\
\text { rência de informação. }\end{array}$ & 1964 & Ciência da Informação & R. S. Taylor \\
\hline $\begin{array}{l}\text { Disciplina que estuda a estrutura da informação científica } \\
\text { e as leis que a regem, assim como sua teoria, história } \\
\text { e métodos. }\end{array}$ & 1967 & Informatika* & A. I. Mikhailov \\
\hline $\begin{array}{l}\text { Organização, ordenação, investigação, difusão e ava- } \\
\text { liação da informação sobre ciências, tecnologias e } \\
\text { artes, registrada em qualquer suporte. }\end{array}$ & 1971 & Documentação & FID \\
\hline $\begin{array}{l}\text { Processo contínuo e sistemático (identificação, coloca- } \\
\text { ção (emprego), aquisição, análise, depósito, recupe- } \\
\text { ração, circulação e conservação de documentos e } \\
\text { dados para usuários especializados). }\end{array}$ & 1976 & Documentação & Gernot Wersig \\
\hline $\begin{array}{l}\text { Análise do conteúdo intelectual da literatura especiali- } \\
\text { zada, sua organização sistemática e sua difusão. }\end{array}$ & 1977 & Documentação & IFLA \\
\hline $\begin{array}{l}\text { Ciência geral que tem por objeto o estudo do processo } \\
\text { de transmissão e recuperação das fontes para a } \\
\text { obtenção de novo conhecimento. }\end{array}$ & 1980 & Documentação & José López Yepes \\
\hline $\begin{array}{l}\text { Armazenamento e investigação da informação } \\
\text { documental em sua relação com a tecnologia. }\end{array}$ & 1981 & Documática & ADBS \\
\hline
\end{tabular}

Fonte: García Gutiérrez (1999).

$\left(^{*}\right)$ García Gutiérrez (1999, p.32) destaca que deve ser observada a diferença de sentido entre a "Informática (igual à Informatologia, nas palavras de Pauline Atherton) e a Informatics = Computing Science anglo-saxônica". 
desenvolvendo as mesmas atividades ou similares. O que dizer do profissional da área de Documentação, o documentalista; da Biblioteconomia, o bibliotecário ou biblioteconomista; da Arquivologia, o arquivista; da Museologia, o museólogo; da Ciência da Informação, o profissional da informação ou cientista da informação. Não são todos eles profissionais que lidam com informação?

\section{Biblioteconomista ou Profissional da Informação: eis a questão!}

A partir das diferentes denominações encontradas na literatura - e atualmente com a inserção das novas TIC, elas têm aumentado ainda mais - questiona-se a real existência, no mercado de trabalho de profissionais registrados com denominações incomuns como bibliodocumentalista, cibertecário, infomediário, entre outras (ALMEIDA JÚNIOR, 2000, p.48). Em que se deve basear a denominação de um profissional? No tipo de material que manipula? Em sua atividade prática? Nas competências que possui? No tipo de instituição em que atua?

Neste sentido, Smit (2000) reconhece que a denominação de Moderno Profissional da Informação (MIP), baseado num estudo desenvolvido pela FID, engloba uma família composta pelos arquivistas, bibliotecários/documentalistas e museólogos, cuja competência específica deve ser o tratamento da informação; elimina-se assim o hábito de denominar-se cada profissional pelo ambiente ou pelas instituições em que atua.

Rezende (2002) destaca que o processo de globalização, o avanço e o desenvolvimento mundial em várias áreas, principalmente a tecnológica, trouxeram a necessidade de que as organizações (basicamente as empresas) passassem a contar com profissionais que auxiliassem na gestão dos negócios. Nesse nicho começam a aparecer na literatura, inclusive da $\mathrm{Cl}$, expressões como agentes do conhecimento, capital intelectual, inteligência empresarial e gestão do conhecimento.
Ainda segundo Rezende (2002, grifos nossos), o grupo de agentes do conhecimento engloba os agentes criativos (que utilizam a informação na solução de problemas); os agentes intérpretes (que interpretam o contexto de atuação da organização e utilizam a informação como ferramenta para gerar novos negócios); os agentes intermediários (que intermediam e favorecem o acesso à informação, desenvolvendo tanto a identificação, quanto a interpretação das demandas de informação do negócio, além de identificarem as fontes de informação mais favoráveis para esse tipo de negócio. Esse grupo é composto quase que exclusivamente por bibliotecários, em virtude da facilidade que têm para organizar e manter os acervos informacionais); e, por último, os agentes do conhecimento (uma nova categoria de profissionais, cuja atividade principal é administrar o capital intelectual das empresas).

A mesma autora ressalta que, as denominações adotadas na prática para essa diferente atuação dos bibliotecários, no nível empresarial, vêm gerando termos mais abrangentes tais como gestores ou profissionais da informação, e que sua área de atuação "deixou de ser chamada de biblioteconomia para ser ciência da informação." (REZENDE, 2002, p.82).

A denominação profissional da informação tem causado grandes discussões e divergências em relação ao perfil do profissional e ao conceito que defina quem é/o que faz esse profissional. Segundo Barbosa (1998, p.53) "não há definição universalmente aceita a respeito do que constitui um profissional de informação."

Nessa categoria já foram incluídos vários profissionais como "pesquisadores, engenheiros, projetistas, desenhistas industriais, gerentes, contadores e todos aqueles eventualmente remunerados para criar conhecimento, comunicar idéias, processar informação". Definições variadas são citadas na literatura, algumas de caráter muito abrangente como "aquele que trabalha com informação em vez de objetos." 
(BARBOSA, 1998, p.53). O autor ainda observa que existem iniciativas por parte de alguns órgãos nacionais de estatísticas de vários países - como Canadá, Estados Unidos e México - em conseguir uma melhor definição de quem/o que são, tanto os profissionais, como as organizações de informação.

Em vista da diversidade de definições citadas é importante frisar que, se a própria área de $\mathrm{Cl}$ ainda está se firmando, ou como dizem Smit e Barreto (2002, p.20) "sofre de indeterminações", o que dizer de um profissional que não sabe a que área pertence? A crise de identidade também é confirmada pelos questionamentos centrados em uma interminável discussão sobre bibliotecário versus profissional da informação, trabalhos técnicos versus trabalhos gerais, sobre o profissional antigo e o moderno (ALMEIDA JÚNIOR, 2000; VALENTIM, 2000; SOUZA, 2001).

A posição de Almeida Júnior (2000, p.31) é a de que existe uma teimosia no emprego do termo bibliotecário para o profissional atuante nesse novo ambiente, pois essa é "uma tentativa de manutenção de uma estrutura não mais condizente com as atuais necessidades sociais". O autor classifica ainda o perfil do bibliotecário como "vinculado a exigências sociais ultrapassadas e retrógradas." (ALMEIDA JÚNIOR, 2000, p.31).

Arruda et al. (2000, p.19) citando os resultados da pesquisa sobre o MPI, realizada pela FID, destacam que a "tecnologia desponta como propulsora das principais modificações". Trazem ainda a observação da vice-presidente da FID, Sra. Margarita Almada de Ascencio:

Nenhum profissional da atualidade tem condições de reunir todas as habilidades, conhecimentos e competências necessários para interagir e equacionar os problemas decorrentes dos fluxos de informação e conhecimento. Para resolvê-los é necessária a formação de equipes interdisciplinares em todos os níveis e processos: estratégicos, gerenciais e operatórios. (ALMADA DE ASCENCIO citada por ARRUDA et al., 2000, p.19).

Para Almeida Júnior (2000, p.32), profissional da informação é um termo, "uma designação não específica do bibliotecário, mas que abrange um grupo de profissionais que atuam tendo como base a informação" em "seus vários aspectos, abordagens, suportes e momentos." (ALMEIDA JÚNIOR, 2000, p.42).

Cunha e Pereira (2003) lembram que as funções dos profissionais consideradas "emergentes”, como gestão, análise da informação e comunicação, não são novas, e que, o que vem mudando não são as atividades e sim os ambientes informacionais, os quais têm ficado cada vez mais diversificados e complexos. As autoras ainda ressaltam que, com o desenvolvimento mundial, a informação passou a ser vista como um ativo fundamental para todos os setores da sociedade.

Valentim (2000, p.139, grifo do autor) entende que o profissional da informação tem um papel de "processador e filtrador da informação" e que deve exercer esse papel "de forma coerente e eficiente, voltado para o usuário/ cliente."

Ponjuán Dante (2000, p.93) entende que o conceito de profissional da informação encontra-se em evolução e coloca como PI todos "aqueles que estão vinculados profissional e intensivamente a qualquer etapa do ciclo de vida da informação". Destaca ainda que esses profissionais devem ser capazes de "operar eficiente e eficazmente em tudo o que é relativo à informação em organizações de qualquer tipo ou em unidades especializadas de informação." (PONJUÁN DANTE, 2000, p.93).

Pegoraro (2001, p.13) ressalta que conceitos abrangentes, como o acima citado, não podem ser aceitos pela área de $\mathrm{Cl}$. Para ela, somente os profissionais que trabalham com a informação como objeto central é que pode- 
riam compor essa categoria. Em outro ponto de sua pesquisa Pegoraro (2001 p.10) afirma que os bibliotecários são também conhecidos como profissionais da informação, o que demonstra a grande confusão em que vivem os próprios trabalhadores a respeito de sua área de atuação. Trabalhos como o de Souza (1994) e de Pegoraro (2001), deixam transparecer que a biblioteconomia não deve ser vinculada ao livro ou à biblioteca e sim à informação, que constitui sua essência.

Sergean, citado por Cunha e Crivellari (2004, p.46), explica a dificuldade para se definir o campo de informação, pela própria natureza da informação: ela não é um campo exclusivo de um grupo profissional, mas "concerne a todos os indivíduos", sendo o trabalho informacional comum a vários profissionais, os quais, em determinadas condições, acabam exercendo atividades de informação.

Cronin, citado por Cunha e Crivellari (2004, p.46), considera que "não existe uma profissão da informação", mas sim, "um grupo grande e heterogêneo de profissionais que podem ser qualificados como tais", pois o espectro de funções desempenhadas, além de suas habilidades, é muito diversificado para concentrá-los sob um mesmo conceito. Para esse autor o termo profissionais da informação é uma "rubrica vaga, conveniente, que pressupõe um conjunto de categorias profissionais e ignora as diferenças de orientação, de formação básica e das atividades por eles exercidas." (CRONIN citado por CUNHA; CRIVELLARI, 2004, p.46).

Diante dessa discussão entende-se que, no contexto atual, marcado pela presença das novas TIC, o termo bibliotecário restringe a atuação desse profissional ao âmbito das bibliotecas, na visão de muitas pessoas. O termo profissional da informação é mais abrangente, porém abarca outros trabalhadores da informação como professores, jornalistas, etc., dificultando a delimitação dos profissionais por área de atuação e interferindo em sua identidade profissional.

Galvin, citado por Barbosa (1998, p.56), considera que o problema já nasce na formação dos profissionais. Destaca a grande proliferação de especializações com as mais diferentes denominações - por exemplo "mestre em gerência de recursos informacionais, especialista em informação geográfica, especialização em sistemas de informações gerenciais" etc. - como responsável por "um quadro confuso para os públicos externos", que, segundo ele, não conseguem entender o que fazem esses profissionais e o que é a Ciência da Informação (BARBOSA, 1998, p.56).

Entende-se que, para que os estudos científicos e pesquisas a respeito dessa categoria possam ocorrer e para que esses estudos retratem a realidade, é preciso uma delimitação clara. Entende-se, ainda, que uma definição mais exata influenciará a visibilidade da categoria por todos os profissionais, inclusive de outras áreas, e ajudará os próprios profissionais da informação a crescerem e amadurecerem.

Esse é um problema a ser enfrentado pelos profissionais da $\mathrm{Cl}$. Vale frisar que, em outras áreas, como Direito, Medicina e Engenharia, as novas tecnologias também trouxeram reflexos na atuação dos seus profissionais, com a utilização de equipamentos cada vez mais modernos e informatizados; entretanto, eles continuam sendo reconhecidos como advogados, médicos e engenheiros.

Inversamente, sabe-se que não adianta mudar a denominação de uma classe profissional sem que se mude, de fato, a postura e a atuação de seus profissionais. Além disso, um grupo profissional precisa possuir uma história e uma tradição para poder ser reconhecido pela sociedade e garantir sua identidade como classe profissional. Entretanto, esse comportamento não descarta a oportunidade de aprender e de adaptar-se ao novo - como às tecnologias. 


\section{Os estudos sobre o Profissional da Informação: o perfil de competências e habilidades}

Inicialmente foram destacados os principais acontecimentos históricos, desde a Antigüidade até os dias atuais, para entender-se como se desenvolveu a profissão do organizador e difusor da informação. Em seguida apresentou-se uma discussão em relação ao bibliotecário e ao documentalista, inclusive sobre a formação desses profissionais. Depois, destacou-se a influência das definições das áreas que tratam a informação na denominação de seus profissionais, trazendo e discutindo os diferentes conceitos apresentados, tanto para as áreas como para os profissionais.

Neste tópico se dará ênfase aos tipos de estudos na área da $\mathrm{Cl}$ que têm tanto o bibliotecário como o profissional da informação como objetos de estudo. A partir dessa discussão pretende-se mostrar quais são os enfoques mais comuns nos estudos do tema, na literatura da área.

O estudo de Cunha e Pereira (2003) investigou a inserção profissional dos egressos do curso de Biblioteconomia da Universidade Federal de Santa Catarina (UFSC) no período de 1991-2000. O método utilizado foi um questionário encaminhado aos profissionais por e-mail e, para alguns entrevistados, foi usado o telefone. Apesar de as autoras destacarem que não atingiram o número desejado de respondentes (apenas 15,8\% dos profissionais formados naquela instituição responderam), conseguiram chegar a algumas conclusões interessantes sobre o perfil profissional dos alunos formados no curso de Biblioteconomia da citada instituição e sobre sua inserção no mercado de trabalho: a predominância dos profissionais da área que responderam, é do sexo feminino; esses profissionais atuam basicamente em universidades privadas no interior de Santa Catarina; as atividades mais desenvolvidas eram análise, referência e gestão da informação. Os conteúdos mais solicitados pelos PI para constarem dos currículos dos cursos de formação em Biblioteconomia são os ligados à Informática e às novas tecnologias.

Pereira (2000) pesquisou a ocorrência do tema 'profissional da informação', enfatizando sua função gerencial, em dois periódicos da área: Ciência da Informação e Perspectivas em Ciência da Informação no período de 1996 a 1999. De acordo com os resultados, o tema foi enfocado pelos dois periódicos durante todo o período estudado, sendo que Ciência da Informação divulgou mais amplamente o assunto. A autora ainda destacou que a maior influência nas citações e referências analisadas foi de autores de língua inglesa. Estudos dessa natureza demonstram que os periódicos científicos, sendo um canal de comunicação entre os pares de qualquer área do conhecimento, são ferramentas importantes, tanto para a discussão de temas de relevância para a área, como para a atualização dos profissionais em relação aos assuntos de pesquisa.

Em relação ao perfil de habilidades e competências dos $\mathrm{PI}$, destacam-se os trabalhos de Marchiori (1996), Ponjuán Dante (2000), Pegoraro (2001), Ferreira (2002) e Neves (2002). Marchiori (1996, p.2) traça primeiramente um paralelo entre a função de bibliotecário e de profissional da informação, ressaltando suas principais diferenças: enquanto ao bibliotecário cabe "adquirir, tratar e conservar materiais bibliográficos e multimeios", ao profissional da informação cabe "identificar a necessidade de informação de seu cliente"; o bibliotecário deve "realizar pesquisas sob demanda", o profissional da informação deve "desenvolver estratégias de busca de informação"; o bibliotecário deve "preservar os materiais" e o profissional da informação "recuperar informação"; o bibliotecário deve "atender ao leitor (quando solicitado)" e o profissional da informação deve "avaliar informação"; o bibliotecário deve ainda "desenvolver 
atividades recreativas e culturais" e o profissional da informação "analisar informação"; ao bibliotecário cabe "oferecer serviços de extensão" e ao profissional da informação cabe "sintetizar informação"; o bibliotecário deve "desempenhar funções administrativas" e o profissional da informação deve "empacotar/re-empacotar informação", devendo ainda o profissional da informação "elaborar e prover produtos e serviços de informação".

Para a autora, o bibliotecário até pode ser um profissional da informação, mas, para isso, deve ter habilidades além das que tradicionalmente possui, entre elas:

\section{- o real conhecimento da informação:}

no sentido de possuir conhecimento técnico, tecnológico e de computadores, aliado a um "profundo entendimento das dinâmicas e fontes de informação, com habilidades interpessoais e empatia para oferecer respostas que possam auxiliar a tomada de decisões de seus clientes"; - dominar habilidades de venda: pelo fato de a informação passar a ser considerada como uma mercadoria (commodity) é preciso que ele possua facilidade para "discutir, implementar e acompanhar os preços e as oportunidades de vendas nas transações, serviços e produtos de informação"; - dominar habilidades afiliativas: estabelecendo alianças e parcerias "com os integrantes da indústria da informação (vendedores, indivíduos com propriedade intelectual, bibliotecas, etc.)." (MARCHIORI, 1996, p.3, grifos do autor).

É preciso salientar que, analisando-se as atividades do bibliotecário e comparando-as com as do profissional da informação, de acordo com a obra de Marchiori (1996), entende-se que um mesmo profissional pode efetuar todos esses serviços.

Ponjuán Dante (2000), comparando vários estudos internacionais a respeito do perfil exigido do profissional da informação para os novos tempos, coteja várias listas de habilidades que os bibliotecários já possuem e outras que eles ainda precisam desenvolver. Em síntese, a partir do levantamento que a autora faz, ela entende que as principais habilidades exigidas estão ligadas "à gestão, à tecnologia, à informação, à biblioteconomia, à comunicação, aos negócios e à cultura geral." (p.97). Destaca, ainda, que o profissional da informação é um agente de mudanças, um educador e um promotor cultural com grande responsabilidade social em sua atuação.

Pegoraro (2001) indica como principais conhecimentos exigidos para o profissional da informação, no século XXI, conhecimento de fontes de informação, de administração e gerência, das tecnologias de informação e de marketing, entre outros. Quanto às competências, chama a atenção para o trato com a informação, o desenvolvimento de produtos e serviços de informação, uso das tecnologias de informação, etc.. Quanto às habilidades básicas, ressalta o domínio de outro idioma, a responsabilidade social, o domínio metodológico para a análise de informações, etc.

Ferreira (2002) comenta que muitos PI concentram sua atuação nos espaços tradicionais da Biblioteconomia e que, apesar de as empresas de recrutamento e seleção terem conhecimento da necessidade de um profissional que lide efetivamente com informação, não o ligam com os profissionais formados pela $\mathrm{Cl}$. A autora afirma que grande parte da população não reconhece a $\mathrm{Cl}$ como uma ciência social aplicada e não entende a atuação de seus profissionais na prática. Segundo Ferreira (2002), as habilidades e competências exigidas pelo mercado são um conjunto formado por atitudes comportamentais, diploma e conhecimento efetivo em determinada área.

Neves (2002) cita entre as características mais requisitadas para esse profissional, as habilidades comportamentais, as quais não advêm de cursos ou estudos e dependem, na maioria das vezes, da iniciativa do próprio trabalhador: por exemplo, a capacidade de atuar 
em equipe, a facilidade de comunicação, a capacidade de identificar e julgar a importância das informações, o envolvimento no cargo, a criatividade, a motivação, a liderança, o dinamismo e a flexibilidade, entre outras.

O trabalho de Tarapanoff et al. (2002) destaca a função social do profissional da informação, como muito ligada à alfabetização em informação, ou seja, a tarefa de promover a formação de uma cultura informacional na sociedade, ajudando-a a melhor utilizar as informações e, nesse sentido, conseguir que ela ingresse na Era da Informação e do Conhecimento com uma visão mais crítica e com mais bagagem, para resolver problemas ou tomar decisões. Nesse trabalho os autores destacam também a info-alfabetização, sendo esta uma parte da alfabetização em informação, em que as pessoas aprendem a usar o computador e acessar as informações desejadas, sempre com uma reflexão crítica sobre elas. Como principais características do profissional da informação apontam a de mediador da informação: "mediador entre o mundo digital e a capacidade real de entendimento do receptor da informação, garantindo a efetiva comunicação e a satisfação da necessidade informacional do usuário dessa tecnologia." (TARAPANOFF et al., 2002, p.4).

Baseando-se na literatura estrangeira, Tarapanoff et al. (2002, p.5), trazem ainda os perfis emergentes relacionados ao novo ambiente, muito influenciado pelas TIC e pelas redes, em que constam:

- os gestores da informação (são os "que mantêm sistemas de informação, sistemas de apoio à decisão e operações similares, no setor público e privado"; entretanto, segundo os autores, esses profissionais "nunca se viram como partícipes da mesma profissão que os bibliotecários, arquivistas ou cientistas da informação");

- os gestores do conhecimento (usam as tecnologias para capturar e distribuir conhecimento para as organizações e têm como responsabilidades "criar a infra-estrutura para a gestão da informação; construir a cultura do conhecimento na organização; e fazer com que tudo dê certo");

- os trabalhadores do conhecimento (grupo formado pelos "gestores do conhecimento, profissionais do conhecimento e empregados (do conhecimento) que compreendem como colocar a informação a serviço da produção"); e

- os engenheiros do conhecimento (termo encontrado na literatura como sinônimo de gestor do conhecimento; entretanto, os autores destacam que "a diferença é que o gerente estabelece a direção que um processo deve tomar, enquanto que o engenheiro desenvolve os meios para executar esta diretiva").

Além desses, Tarapanoff et. al. (2002, p.6) destacam os especialistas: especialistas em gestão do conhecimento (profissionais cujas funções "já eram desempenhadas por profissionais como os documentalistas, o pessoal ligado ao treinamento, analistas de negócios e especialistas de apoio ao desenvolvimento organizacional"); especialistas em conteúdos informacionais (campo onde podem atuar os bibliotecários como especialistas de informação, geralmente ocupado por profissionais independentes, como consultores em que a principal função é "prover serviços de informação"); especialistas em uso de ferramentas inteligentes (o profissional que deve "entender os processos computacionais, formatos-padrão, linguagens e softwares; deve também saber gerenciar a informação"). Depois desta longa explanação de perfis emergentes, os autores concluem que

[...] é impossível encontrar, em apenas uma profissão ou em um determinado perfil, a síntese de atividades que compreenda todas as facetas da infor- 
mação e do conhecimento necessárias para o desenvolvimento das atividades de organização ou do desenvolvimento de uma sociedade. (TARAPANOFF et al., 2002, p.7).

A pesquisa de Arruda et al. (2000) focou a atuação dos bibliotecários no novo ambiente, em que o trabalho em si vem sofrendo inúmeras transformações. Segundo os autores, o novo cenário passou a exigir maior número de competências tanto por parte dos $\mathrm{PI}$, como de outros profissionais; portanto, o trabalhador deve ser mais qualificado, e o bibliotecário precisa se adequar às exigências do mercado para melhorar sua colocação e conquistar novas possibilidades de trabalho, aliando a educação continuada às competências pessoais.

Note-se que há uma divergência nas posições abordadas acima, a de Arruda et al. (2000) e a de Cunha e Pereira (2003): a primeira pesquisa constatou mudanças no trabalho dos bibliotecários nos dias atuais e a segunda afirma que o que tem sofrido alterações não são as atividades e sim os ambientes.

A pesquisa de Cronin et al. (1993) procurou identificar o mercado emergente para os $\mathrm{PI}$ no estado de Indiana, nos Estados Unidos. O estudo baseou-se em entrevistas com profissionais atuantes e na análise de anúncios de emprego publicados em Indianapolis Star, The New York Times, ASIS Jobline, Information Today, Library Journal e SpeciaList. Alguns resultados, que puderam ser generalizados, indicam existir um mercado mensurável para os PI, exigindo deles um "mix de talentos, know-how e experiência" (p.3); entretanto, esse mercado é difuso e não deve fidelidade a qualquer corpo profissional estabelecido ou a qualquer curso disciplinar; os títulos e funções de trabalho são extremamente variadas; as escolas de Biblioteconomia e $\mathrm{Cl}$ precisam rever, não somente seus currículos, como também a própria cultura, para que seus profissionais possam ter mais êxito no mercado de trabalho; o nível de mestrado (ou em alguns casos Master on Business Administration -MBA) tem sido uma exigência comum dos empregadores e, quando não exigido, é bem visto o profissional que o possua; além disso, uma larga experiência em determinado campo pode contar tanto quanto uma pós-graduação.

As mais variadas denominações são encontradas para as funções e destacam-se algumas: "especialista de dados; analista de mercado de informação, cientista da informação, especialista de tecnologia da informação, gerente de serviços de informação; coordenador de informação de mercado; indexador de documentos jurídicos" entre tantos outros (CRONIN et al., 1993, p.4).

Valentim (2000), tratando das perspectivas profissionais e atuação dos $\mathrm{PI}$, entende que o mercado de trabalho do profissional bibliotecário se divide em três grandes grupos: 1) o mercado informacional tradicional - composto por bibliotecas públicas, escolares, universitárias, especializadas (pertencentes a institutos de pesquisa e a empresas públicas ou privadas), centros culturais, bibliotecas de arquivos e de museus; 2) os mercados informacionais existentes e não ocupados (ou pouco ocupados) - de que fazem parte as bibliotecas escolares (que segundo a autora não é um mercado de trabalho totalmente aproveitado devido aos baixos salários e à estrutura de trabalho inadequada, entre outros obstáculos), editoras, livrarias, empresas privadas, provedores de internet, bancos e bases de dados, além de consultorias e assessorias (com atuação dos PI como profissionais autônomos ou terceirizados); 3 ) as tendências de mercado informacional - são caracterizadas pela autora como um imenso e crescente mercado de trabalho, aberto aos $\mathrm{PI} e$ calcado no paradigma da informação.

O estudo de Smit e Barreto (2002) desenvolve a relação entre o profissional e sua área formadora, ressaltando a importância de que este tenha pleno conhecimento do arcabouço teórico 
de seu campo de formação e trabalho. Em conseqüência dessa ligação, fica clara a importância da pesquisa na formação dos PI, para que estes se aprofundem nos aspectos conceituais da área e para que possam desenvolvê-la ainda mais com a execução de novas pesquisas. Os autores trazem ainda um importante conceito de informação, a ser destacado, em que ela é vista como

[...] estruturas simbolicamente significantes, codificadas de forma socialmente decodificável e registradas (para garantir permanência no tempo e portabilidade no espaço) e que apresentam a competência de gerar conhecimento para o indivíduo e para o seu meio. Estas estruturas significantes são estocadas em função de um uso futuro, causando a institucionalização da informação. (SMIT; BARRETO, 2002, p.21).

A discussão dos autores é extremamente interessante por ressaltar alguns pontos-chave a respeito da informação como objeto de trabalho do profissional da informação: o caráter decodificável da informação (para que seja utilizada); a necessidade de que seja registrada em qualquer suporte (para diferenciar informação volátil, como a tácita, de uma informação que foi registrada com a intenção de ser socializável); além de a informação ser socializável, ela é reunida em estoques de acordo com uma utilidade que lhe foi atribuída, seja por uma instituição, um governo ou qualquer agente; possuindo um caráter institucional, a informação torna-se social. É a partir dessa cadeia, e com esse enfoque, que deve trabalhar o profissional da informação.

\section{Os estudos sobre o profissional da informação: inserção no mercado de trabalho}

Outra linha de trabalhos na área de Ciência da Informação tem procurado investigar, em uma perspectiva empírica mais geral, a questão da inserção dos PI no mercado de trabalho. Nesta linha, têm destaque as pesquisas de Jannuzzi e Mattos (2001) e de Bueno (2004).

Baseando-se no conceito de profissional da informação de Ponjuán Dante (2000), já citado neste trabalho, aparece a pesquisa sobre a inserção dos PI no Brasil, no período de 1980 até 1996, de Jannuzzi e Mattos (2001). Os autores incluíram nessa categoria bibliotecários, arquivistas, museólogos, analistas de sistemas e estatísticos, analistas socioeconômicos e professores universitários, jornalistas e escritores. Os resultados apontaram que os $\mathrm{PI}$, como outras categorias no país, também sofreram problemas de inserção por influência econômica (como exemplo, cita-se a época de recessão devida ao plano Collor); entretanto, segundo os autores, os $\mathrm{PI}$ conseguiram manter níveis de proteção social e direitos básicos bastante superiores em relação aos demais trabalhadores de outras categorias; quanto aos salários, dentre a média dos ocupados, os dos PI eram duas a cinco vezes maiores.

Estudando a economia da informação no Brasil, Bueno (2004) destacou a atuação dos $\mathrm{PI}$, que movimenta a economia com a produtividade de seu trabalho e também com os ordenados e salários desses profissionais no mercado. Baseando-se na metodologia de Porat (1977), o autor utilizou os microdados do Censo Demográfico de 2000 para identificar, delimitar, dimensionar e caracterizar as atividades baseadas em informação, em termos econômicos, no Brasil. De acordo com Schement citado por Bueno (2004, p.44):

[...] trabalho de informação ocorre quando a principal tarefa do trabalhador envolve de alguma forma processamento ou manipulação da informação, tais como produção, reciclagem, ou manutenção da informação. Além do mais, a conseqüência do trabalho da informação é mais informação, seja na forma de novo conhecimento, seja reelaborado nas formas 
existentes. Diferente do trabalhador da linha de montagem, um trabalhador da informação, tal como uma telefonista, processa e manipula informação como um fim em si mesmo. A informação define a tarefa, o produto, e o trabalhador.

O grupo estudado por Bueno (2004, p.74), chamado de trabalhadores da informação, seria formado por produtores, processadores, distribuidores de informação e, no Brasil, mais da metade seria representado pelos processadores da informação (58\%, perto de 6,79 milhões de pessoas). Em relação ao perfil educacional, os trabalhadores da informação superam a média dos demais trabalhadores, pelo fato de sua atividade exigir maior número de habilidades e conhecimentos.

\section{CONSIDERAÇÕ ES FINAIS}

Destaca-se o registro da informação como ponto fundamental para o nascimento das profissões ligadas à organização e à difusão de informações. O histórico apresentado destaca a profissão de bibliotecário, que se formou inicialmente pautada em largo conhecimento cultural e humanístico, passando até a ser considerada elitista, devido ao grande conhecimento e erudição de seus profissionais, para depois mergulhar na técnica, perdendo sua visão crítica e chegando a ser considerada reduto de pessoas "bondosas, porém incompetentes, verdadeiras guardiãs num depósito de documentos". Com o advento das TIC, a categoria resolveu assimilar o ambiente virtual como campo de trabalho e optou pela mudança de denominação, atitude que não foi aceita em consenso pela totalidade da comunidade científica da área.

Argumenta-se que esse posicionamento dá ingresso aos profissionais de outras áreas, com conhecimentos práticos de informática, tão necessários para se atuar no meio virtual. Será que os bibliotecários estarão prontos para assumir essa empreitada? Nesse sentido, mais uma vez, a categoria poderá sofrer prejuízos, pois a atuação em uma profissão depende tanto do domínio de técnicas específicas e das competências de inserção no mercado de trabalho, quanto das necessidades criadas por esse mercado, além de estar ligada ao próprio reconhecimento da função da classe pela sociedade.

A ligação do termo bibliotecário com o livro e os objetos culturais não deveria ser motivo de vergonha, mas sim de orgulho. As entidades de área deveriam se organizar no sentido de mobilizar as autoridades em relação a investimentos na área de Bibliotecas públicas e escolares, destacando-se aí, a função de educador do PI. O incentivo à cultura no Brasil é fundamental para melhorar o ambiente atual.

O quadro teórico esboçado mostrou um grande número de trabalhos que enfocam o perfil dos PI, suas habilidades e competências, principalmente em relação ao que o mercado de trabalho exige.

Depois desse percurso, finaliza-se ressaltando que o conceito de Profissional da Informação precisa ser mais discutido, para ser definido e aceito pela comunidade, visando fortalecer a categoria. Segundo esta pesquisa entende-se que o conceito de Profissional da Informação ainda encontra-se em construção.

\section{REFER Ê NCIAS}

ALMEIDA JÚNIOR, O.F. Profissional da informação: entre o espírito e a produção. In: VALENTIM, M.L.P. (Org.). O profissional da informação: formação, perfil e atuação profissional. São Paulo: Pólis, 2000. p.31-51.
AMERICAN SOCIETY FOR INFORMATION SCIENCE AND TECHNOLOGY. ASIS\&T and its members. Available from: <http://www.asis.org/ AboutASIS/the-society.html>. Acess: 9 Dec. 2004. 
ARRUDA, M.C.C.; MARTELETO, R.M.; SOUZA, D.B. Educação, trabalho e o delineamento de novos perfis profissionais: o bibliotecário em questão. Ciência da Informação, Brasília, v.29, n.3, p.14-24, 2000.

BARBOSA, R.R. Perspectivas profissionais e educacionais em Biblioteconomia e Ciência da Informação. Ciência da Informação, Brasília, v.27, n.1, p.53-60, 1998.

BATTLES, M. A conturbada história das bibliotecas. São Paulo: Planeta, 2003. 239p.

BOTTENTUIT, A.; CASTRO, C. Movimento fundador da biblioteconomia no Maranhão. São Luís: UFMA, 2000. 118p.

BUCKLAND, M.K. Information as thing. Journal of the American Society for Information Science, v.42, n.5, p.351-150, 1991.

BUENO, M.F. A economia da informação no Brasil: dimensionamento e caracterização do setor de informação através das ocupações do Censo Demográfico 2000. 2004. 110f. Dissertação (Mestrado em Ciência da Informação) - Pós-Graduação em Biblioteconomia e Ciência da Informação, Pontifícia Universidade Católica de Campinas, Campinas, 2004.

BURKE, P. Uma história social do conhecimento: de Gutenberg a Diderot. Rio de Janeiro: Jorge Zahar, 2003. 241p.

CÂNFORA, L. A biblioteca desaparecida: histórias da biblioteca de Alexandria. São Paulo: Companhia. das Letras, 1996. 195p.

CHARTIER, R. A ordem dos livros: leitores, autores e bibliotecas na Europa entre os séculos XIV e XVIII. Brasília: UnB, 1994. 111p. (Coleção Tempos).

CRONIN, B.; STIFFLER, M.; DAY, D. The emergent market for information professionals: educational opportunities and implications. Library Trends, v.42, n.2, p.257, 1993. Available from: <http:// www.portaldapesquisa.com.br/databases/ sites ?area $=$ humanas $\&$ search $=$ graduates + and + information+science \&cust=copere\&action $=$ present $\&$ lastaction $=$ search $\&$ pub $=$ gale $\& d b=i t o f \& r i=1 \& r f=10>$. Acess: 29 Mar. 2004.

CUNHA, M.V. A formação dos profissionais da informação na França: comparação com o sistema brasileiro. In: VALENTIM, M.L.P. (Org.). O profissional da informação: formação, perfil e atuação profissional. São Paulo: Polis, 2000. p.71-90.
CUNHA, M.V.; PEREIRA, M.C. Perfil do profissional da informação em Santa Catarina: primeiros resultados. In: ENCONTRO NACIONAL DE PESQUISA EM CIÊNCIA DA INFORMAÇÃO, 5., 2003, Belo Horizonte. Anais... Belo Horizonte: UFMG, 2003. 1 CD-ROM.

CUNHA, M.V.; CRIVELLARI, H.M.T. O mundo do trabalho na sociedade do conhecimento e os paradoxos das profissões da informação. In: VALENTIM, M.L.P. (Org.). Atuação profissional na área de informação. São Paulo: Polis, 2004. p.39-54.

DAMASIO, E. O profissional da informação na indústria: habilidades e competências. 2001. 110f. Dissertação (Mestrado em Biblioteconomia e Ciência da Informação) - Mestrado Interinstitucional PUCCAMP/UFPR, Pontifícia Universidade Católica de Campinas, Campinas, 2001.

FERREIRA, D.T. Profissional da informação: perfil de habilidades demandadas pelo mercado de trabalho. 2002. 114f. Dissertação (Mestrado em Biblioteconomia e Ciência da Informação) - PósGraduação em Biblioteconomia e Ciência da Informação, Pontifícia Universidade Católica de Campinas, Campinas, 2002.

FONSECA, E.N. A biblioteconomia brasileira no contexto mundial. Rio de Janeiro: Tempo Brasileiro, 1979. 112p.

FONSECA, E.N. Introdução à Biblioteconomia. São Paulo: Pioneira, 1992. 145p. (Manuais de estudo). GARCÍA GUTIÉRREZ, A. Aproximación al concepto y al objeto de la información/documentación. In: Introducción a la documentación informativa y periodística. Sevilla: MAD, 1999. p.23-61.

GEORGE JÚNIOR, C.S. História do pensamento administrativo. São Paulo: Cultrix, 1972. p.22-23.

GUIMARÃES, J.A.C. O profissional da informação sob o prisma de sua formação. In: VALENTIM, M.L.P. (Org.). O profissional da informação: formação, perfil e atuação profissional. São Paulo: Polis, 2000. p.53-70.

HJØRLAND, B. Library and information science: practice, theory, and philosophical basis. Information Processing \& Management, v.36, p.501-531, 2000.

JANNUZZI, P.M.; MATTOS, F.A.M. Duas décadas de conjuntura econômica, de (des)emprego industrial e de inserção dos profissionais da informação no mercado de trabalho. Transinformação, Campinas, v.13, n.2, p.111-129, 2001. 
KOBASHI, N.Y. Análise documentária e representação da informação. Informare: Cadernos do Programa de Pós-Graduação em Ciência da Informação, Rio de Janeiro, v.2, n.2, p.5-27, 1996.

LE COADIC, Y-F. Science de I' information. In: CACALY, S. (Ed.). Dictionnaire encyclopédique de l'information et de la documentation. Paris: Nathan, 1997. p.516-523.

LITTON, G. A documentação. São Paulo: McGraw Hill, 1976. 187p. (Série de Biblioteconomia, 12).

MARCHIORI, P.Z. Eram os deuses astronautas? ou são os bibliotecários profissionais da informação? São Paulo: Associação Paulista de Bibliotecários, 1996. 12p. (Ensaios APB, n.34).

MARTINS, W. A palavra escrita: história do livro, da imprensa e da biblioteca: com um capítulo referente à propriedade literária. 2.ed. São Paulo: Ática, 1996. 519p. (Série Temas, v.49).

McGARRY, K. Armazenamento e recuperação de informações na sociedade. In: McGARRY, I. O conceito dinâmico da informação: uma análise introdutória. Brasília: Briquet de Lemos/Livros, 1999. p.111-142.

MELLO, J.B. Bibliotecas. In: MELLO, J.B. Síntese histórica do livro. 2.ed. São Paulo: Ibrasa, 1979. p.206-213. (Biblioteca "história", 28).

MEY, E.S.A. Introdução à catalogação. Brasília: Briquet de Lemos/Livros, 1995. 123p.

MUELLER, S.P.M. Uma profissão em evolução: profissionais da informação no Brasil sob a óptica de Abbott: proposta de estudo. In: BAPTISTA, S.G.; MUELLER, S.P.M. (Org.). Profissional da informação: o espaço de trabalho. Brasília: Thesaurus, 2004. p.23-54. (Estudos avançados em Ciência da Informação, v.3).

NEVES, E.C. Profissional da informação: habilidades e competências na Era do Conhecimento. 2002. 125f. Dissertação (Mestrado em Biblioteconomia e Ciência da Informação) - Pós-Graduação em Biblioteconomia e Ciência da Informação, Pontifícia Universidade Católica de Campinas, Campinas, 2002.

NOVA ENCICLOPÉDIA BARSA. Rio de Janeiro: Encyclopaedia Britannica do Brasil, 1999. 1 CD-ROM.

OLIVEIRA, Z.C.P. O bibliotecário e sua auto-imagem. São Paulo: Pioneira, 1983. 98p.

PEGORARO, E.F. O profissional de informação do século XXI: um referencial de conhecimentos, competências e habilidades necessárias para sua atuação. 2001. 96f. Dissertação (Mestrado em Biblioteconomia e Ciência da Informação) - Mestrado Interinstitucional PUCCAMP/UFPR, Pontifícia Universidade Católica de Campinas, Campinas, 2001.

PEREIRA, J.D.S. Função gerencial do profissional da informação na área de Biblioteconomia: divulgação do assunto em periódicos nacionais. In: SEMINÁRIO NACIONAL DE BIBLIOTECAS UNIVERSITÁRIAS DAAMÉRICA LATINA, SIMPÓSIO DE BIBLIOTECAS UNIVERSITÁRIAS DAAMÉRICA LATINA E DO CARIBE, SIMPÓSIO DE DIRETORES DE BIBLIOTECAS UNIVERSITÁRIAS DAAMÉRICA LATINA E DO CARIBE, 11., 2000, Florianópolis. Anais... Florianópolis: Universidade Federal de Santa Catarina, 2000. Disponível em: <http:// snbu.bvs.br/SNBU2000/docs/pt/doc/t096.doc>. Acesso em: 1 mar. 2004.

PONJUÁN DANTE, G. Perfil del profesional de información del nuevo milenio. In: VALENTIM, M.L.P. (Org.). O profissional da informação: formação, perfil e atuação profissional. São Paulo: Polis, 2000. p.91-105.

PORAT, M.U. The information economy: definition and measurement. US Department of Commerce, 1977. 249p. (OT Special Publication 77-12; v.1).

REZENDE, Y. Informação para negócios: os novos agentes do conhecimento e a gestão do capital intelectual. Ciência da Informação, Brasília, v.31, n.1, p.75-83, 2002.

ROBREDO, J.; CUNHA, M.B. Documentação de hoje $e$ de amanhã: uma abordagem informatizada da biblioteconomia e dos sistemas de informação. São Paulo: Global, 1994. 400p. (Coleção Ciência da Informação e Educação).

RODRIGUES, M.E.F. Relação ensino-pesquisa: em discussão a formação do profissional da informação. DataGramaZero, v.3, n.5, out. 2002. Disponível em: <http://www.dgz.org.br/out02/ F_I_art.htm>. Acesso em: 12 mar. 2004.

SARACEVIC, T. Interdisciplinary nature of information science. Ciência da Informação, Brasília, v.24, n.1, p.36-41, 1995.

SHERA, J.H. Sobre biblioteconomia, documentação e ciência da informação. In: GOMES, H.E. (Org.). Ciência da informação ou informática? Rio de Janeiro: Calunga, 1980. p.91-105.

SMIT, J.W. Análise documentária: breve histórico. [S. I.: s. n.], 1996. 12p. Mimeografado. 
SMIT, J.W. O profissional da informação e sua relação com as áreas de Biblioteconomia/Documentação, Arquivologia e Museologia. In: VALENTIM, M.L.P. (Org.). O profissional da informação: formação, perfil e atuação profissional. São Paulo: Polis, 2000. p.119-134.

SMIT, J.W.; BARRETO, A.A. Ciência da informação: base conceitual para a formação do profissional. In: VALENTIM, M.L.P. (Org.). Formação do profissional da informação. São Paulo: Polis, 2002. p.9-23.

SOUZA, M.A. Bibliotecário: atuação no mercado de trabalho da cidade de São Paulo. 1994. 117f. Dissertação (Mestrado em Biblioteconomia) - PósGraduação em Biblioteconomia, Pontifícia Universidade Católica de Campinas, Campinas, 1994.

SOUZA, M.I.F.; VENDRUSCULO, L.G.; MELO, G.C. Metadados para a descrição de recursos de informação eletrônica: utilização do padrão Dublin Core. Ciência da Informação, Brasília, v.29, n.1, p.93-102, 2000.

SOUZA, F.C. A escola de biblioteconomia e a ancoragem da profissão de bibliotecário. Informação e Sociedade: Estudos, João Pessoa, v.11, n.2, p.125-144, 2001.

TARAPANOFF, K.; SUAIDEN, E.; OLIVEIRA, C.L. Funções sociais e oportunidades para profissionais da informação. DataGramaZero, v.3, n.5, out. 2002. Disponível em: <http://www.dgz. org.br/out02/F_I_art.htm>. Acesso em: 12 mar. 2004.

VALENTIM, M.L.P. Atuação e perspectivas profissionais para o profissional da informação. In: VALENTIM, M.L.P. (Org.). O profissional da informação: formação, perfil e atuação profissional. São Paulo: Polis, 2000. p.135-152. 
